\title{
The International Diversification Puzzle When Goods Prices Are Sticky: It's Really about Exchange-Rate Hedging, Not Equity Portfolios
}

\author{
By Charles Engel and Akito Matsumoto*
}

\begin{abstract}
This paper develops a two-country monetary DSGE model in which households choose a portfolio of home and foreign equities, and a forward position in foreign exchange. Some nominal goods prices are sticky. Trade in these assets achieves the same allocations as trade in a complete set of nominal state-contingent claims in our linearized model. When there is a high degree of price stickiness, we show that not much equity diversification is required to replicate the complete-markets equilibrium when agents are able to hedge foreign exchange risk sufficiently. Moreover, temporarily sticky nominal goods prices can have large effects on equity portfolios even when dividend processes are very persistent. (JEL E13, F41, G11, G15)
\end{abstract}

\begin{abstract}
$\mathrm{n}$ an open macroeconomy, in which asset trade is possible, the portfolio choice of households may play an important role in understanding macro fluctuations. In contrast to a closed economy model, in which a representative agent simply holds the market portfolio, agents in each country may hold different portfolios depending on the country-specific risks and returns that they encounter. Robert E. Lucas, Jr. (1982) provides a fully optimizing model of portfolio balance in which households trade bonds, equities, and claims to monetary transfer from the government. Lucas (1982) and subsequent fully worked-out portfolio balance models have assumed complete nominal goods price flexibility. However, models with sticky nominal goods prices might be appropriate for the consideration of the real consequences of nominal exchange rate fluctuations. Indeed, as we show, the equilibrium portfolio may depend, in important ways, on short-run goods pricing behavior.
\end{abstract}

\footnotetext{
* Engel: Department of Economics, University of Wisconsin, 1180 Observatory Drive, Madison, WI 53706 (e-mail: cengel@ssc.wisc.edu); Matsumoto: Research Department, International Monetary Fund, 700 19th Street, N.W. Washington, DC 20431 (e-mail: amatsumoto@imf.org). We are very grateful to Mark Gertler, Olivier Jeanne, Karen Lewis, Maury Obstfeld, Paolo Pesenti, Cedric Tille, Eric van Wincoop, Frank Warnock, two anonymous referees, and seminar participants at several institutions for helpful comments. Engel acknowledges support from the National Science Foundation through grant SES-0451671 to the University of Wisconsin. The views expressed in this paper are those of the authors and do not necessarily represent those of the Federal Reserve System, the International Monetary Fund (IMF), or IMF policy. Earlier drafts of this paper were circulated under the title "Home Bias in Equities under New Open Economy Macroeconomics," "Portfolio Choice and Home Bias in Equities in a Monetary Open-Economy DSGE Model," and "Portfolio Choice and International Risk Sharing in a Monetary Open-Economy DSGE Model."

${ }^{\dagger}$ To comment on this article in the online discussion forum, or view additional materials, visit the articles page at: http://www.aeaweb.org/articles.php?doi=10.1257/mac.1.2.155.
} 
This paper makes two main contributions.

First, we show that when there is a high degree of nominal goods price stickiness, the availability of a foreign-exchange hedge may play a key role in international risk sharing. Specifically, we consider a model in which agents can trade equity shares and a forward position in foreign exchange. There are real productivity shocks and nominal monetary shocks in our model. With this limited menu of assets, the equilibrium mimics the complete markets outcome-real allocations are the same as if a complete set of nominal contingent claims were traded. But the portfolios that optimally spread risk may not exhibit much equity diversification. If agents can diversify against risk arising from nominal exchange rate fluctuations, with sufficient nominal price stickiness, diversification in the equity portfolio need be minimal. That is, equilibrium portfolios might exhibit home bias. The basic notion is that the shocks that affect relative consumption risk across countries operate through their effects on relative prices (the real exchange rate and the terms of trade) when equity portfolios are not diversified. In the short run, when nominal goods prices are sticky, much of that risk can be hedged on forward foreign exchange markets.

In a sense, we have recast the international portfolio diversification puzzle. If goods prices are sticky, we argue that it is not the equity portfolio that bears most of the burden of risk sharing, but, rather, the foreign exchange position. The optimal exchange-rate hedge requires that agents go long in their own currency and short in foreign currency. The real puzzle about international diversification may turn out to be about the foreign exchange denomination of nominal assets in international portfolios rather than the composition of the equity portfolio. 1

Second, it might seem that price stickiness should be a minor consideration for asset demands. The value of an asset is determined by the expected present discounted value of its current and future payouts. Since persistent productivity shocks drive the real payoffs of assets, price stickiness should have only a small effect on the expected present value. One of the central insights of this paper is that transitory price stickiness can have a large impact on international asset choice. It draws on the observation that, under flexible goods prices, terms-of-trade changes can provide substantial insurance for productivity shocks, even in the absence of trade in assets. For example, a negative domestic productivity shock reduces the supply of home goods, but the effects of this shock on home income can be offset, to some extent, by an increase in the relative price of exports. If prices are flexible, portfolio diversification may not increase expected utility much because of the automatic risk diversification from the terms-of-trade adjustment. However, the risks encountered under sticky prices cannot be insured by terms-of-trade movements. While these risks may be only transitory, they might have a dominant role in portfolio choice because the portfolio is the only means of insuring against these shocks. When prices are sticky, the mix of home and foreign equities can differ dramatically from the mix under flexible prices, even when prices adjust relatively rapidly.

\footnotetext{
${ }^{1}$ We say "may" because, in fact, little is known about the actual foreign exchange denomination of nominal assets, especially because information on derivative holdings is scarce.
} 
Empirical studies have found that foreign equities comprise a small proportion of investors' portfolios ${ }^{2}$ This finding is puzzling because it appears that investors are forgoing important opportunities for diversification of risk. ${ }^{3}$ While there have been many suggested resolutions to the puzzle, none seem able to explain entirely the extent of home bias. Our results show that if agents take an optimal exchange-rate hedge, equity portfolio diversification might not be important. But this conclusion requires that agents fully hedge foreign exchange risk.

Our model is related to one thread of the literature that has attempted to explain home bias as a hedge against nontradable risks. 4 That literature points out that if nontraded labor income is negatively correlated with returns to domestic equities, then domestic equities serve as a hedge for labor income. That hedging incentive leads to home bias in equity portfolios. There is considerable dispute over whether this could explain home bias. In neoclassical models, because labor income is correlated more with domestic firms' profits than with foreign firms' profits, the optimal portfolio will be more foreign-weighted than the classical endowment model predicts, as shown in Baxter and Jermann (1997). There have been some attempts to generalize the neoclassical model to generate this negative covariance of returns to human capital and domestic equities. ${ }^{5}$ The empirical evidence on this correlation is mixed. 6

When an exchange-rate hedge is available, it is not the unconditional correlation between relative equity returns and returns to human capital that is important for equity choice. What matters is the correlation conditioning on the nominal exchange rate, when nominal goods prices are sticky. We develop a model in which the unconditional correlation between the return to human capital, and the return to domestic equities relative to foreign equities, could be positive, but may be negative, conditional on the nominal exchange rate.

In the past few years, there have been many new dynamic models of portfolio choice in general equilibrium. Particularly relevant are the studies that use approximation methods, similar to those used in this paper, to analyze the dynamics of portfolios. In particular, several recent papers have developed, generalized, and formalized the approximation method that we introduced in this paper. Michael B. Devereux and Alan Sutherland (2006) derive an approximation method for an

\footnotetext{
${ }^{2}$ Kenneth R. French and James M. Poterba (1991); Linda L. Tesar and Ingrid M. Werner (1995); and Francis E. Warnock (2002), for example.

${ }^{3}$ Karen K. Lewis $(1999,2000)$ surveys the literature on this puzzle and discusses the losses from nondiversification.

${ }^{4}$ On the role of nontraded goods, see Rafael Eldor, David Pines, and Abba Schwartz (1988); Alan C. Stockman and Harris Dellas (1989); Tesar (1993); Marianne Baxter, Urban J. Jermann, and Robert G. King (1998); and Paolo Pesenti and Eric van Wincoop (2002).

${ }^{5}$ Ignacio Palacios-Huerta (2001) claims that a substantial fraction of home bias can be explained when the differential human capital of stockholders and nonstockholders is taken into account along with human capital frictions. Jonathan Heathcote and Fabrizio Perri (2008) show that in a two-good model with investment there may be home bias in an neoclassical setting. Nicolas Coeurdacier, Robert Kollmann, and Philippe Martin (forthcoming) introduce ad hoc "redistributive shocks" in order to generate negative correlation between labor income and profits in a neoclassical model. See also Jermann (2002), Christian Julliard (2004), and Akito Matsumoto (2007).

${ }^{6}$ Baxter and Jermann (1997) produce evidence that the covariance is positive. Laura Bottazzi, Pesenti, and van Wincoop (1996), and Julliard (2002), produce evidence to suggest that outside the United States there is a weak negative correlation between returns to human capital and domestic equities. See Hanno Lustig and Stijn van Nieuwerburgh (2008) for evidence that returns to human wealth are negatively related to returns to firm owners.
} 
economy with incomplete markets but constant portfolio shares, and apply it to a two-country general equilibrium model with production and trade in equities, and to a two-country endowment model with trade in real bonds. Devereux and Sutherland (2008a) apply this model to a sticky-price monetary model that allows for portfolios of bonds and equity trade. Devereux and Sutherland (2007) extend the approximation method to allow for time-varying portfolios, and apply the method to a two-country endowment model with trade in real bonds. Devereux and Sutherland (2008b) examine a similar model, with a focus on the role of changes in valuation for the international distribution of wealth. Cedric Tille and van Wincoop (2008a) use a similar approximation to solve a two-country general equilibrium model with capital and production and trade in equities. Tille and van Wincoop (2008b) use these methods to examine the response of the current account and net foreign assets to changes in saving. Also, Martin D. D. Evans and Viktoria Hnatkovska (2008) examine a similar model with a related solution methodology. Our paper does not require the generalized approach to approximating the models introduced in these papers because we examine a model in which the menu of assets introduced leads to a complete-markets allocation (to a first-order approximation) with constant portfolios.

In the following sections, we present two kinds of models. The first is static. It is much easier to understand the economic forces at work in the relatively simple static model, but the intuition at which we arrive carries over to the second model, which is a more realistic dynamic one.

\section{A General Result in a Static Framework}

In this section, we present a simple model to illustrate the key mechanism underlying our claim that, when nominal prices are sticky, trade in a foreign exchange hedge can carry much of the burden of international risk diversification. The idea builds from a more general point, which is that, except in some special cases, country risk is reflected in fluctuations in international relative prices - real exchange rates and the terms of trade. If agents can trade assets that hedge these risks, then international trade in equities may not be important (and, in the special case of the model presented in this section, is redundant). This analysis extends ideas first presented in Harold L. Cole and Maurice Obstfeld (1991).

To consider international risk sharing, we simplify the internal economy to have a representative household/investor, and look at a two-country world. Call these two countries Home and Foreign. Suppose that goods produced in one country are imperfect substitutes for goods produced in the other country. If there is a stable demand function for these goods (not subject to preference shocks), then aggregate demand for one country's goods relative to the other country's goods will depend only on the relative prices of Home/Foreign goods in each country, and the consumption real exchange rate. This conclusion, as we will see shortly, follows from a first-order approximation to demand functions assuming homothetic preferences.

What is the bearing of this insight on the question of international portfolio choice? Suppose there is no international trade in equities, so households own their own country's equities and no foreign equities. In that case, household income is tied directly to the sales of firms in that country. The distribution of revenues between 
labor income and profits is irrelevant, since all revenues accrue to the same representative household. If revenues of Home firms relative to Foreign firms are related to relative prices, then Home relative to Foreign income will be as well. Instruments that allow hedging relative prices will then hedge relative income. This conclusion requires that Home and Foreign goods not be perfect substitutes, because, in that special case, Home relative to Foreign revenues will not depend on relative prices.

We build a general-equilibrium, two-country model with sticky prices to show how a nominal exchange-rate hedge can diversify all Home relative to Foreign risk in a static setting. The world population is normalized to unity; half the population lives in Home and half in Foreign. Outcomes are uncertain initially. We assume that goods prices must be set prior to the realization of the state. There is also initial asset trade that allows Home and Foreign households to hedge risk.

In Section II, we fully specify a general equilibrium model, a model which we extend to the dynamic setting in Section III. But, here, we use only some of the features of the model (demand functions for goods, market-clearing conditions, and a general assumption about nominal price stickiness) to demonstrate that a foreign exchange hedge allows households to diversify risk fully in the static setting.

In the models we consider, there is no physical capital. Firms have value because they are monopolistic. Each firm produces a unique good and earns monopoly profit. Households are endowed with ownership in firms in their own country, and with human capital. But, here, we will consider the case in which equities are not tradable. We will posit that trade in other assets, such as a forward position in foreign exchange, takes place prior to the realization of the state. Under this assumption, any portfolio will have a net worth of zero ex ante.

The ex post budget constraint of a representative Home household can be written in log-linearized form as

$$
p_{t}+c_{t}=\zeta h_{t}+(1-\zeta) \pi_{t}+\kappa_{t}
$$

In the models we consider, preferences are homothetic. $c_{t}$ is the log of aggregate consumption, and $p_{t}$ is the $\log$ of the consumer price index ${ }^{7} h_{t}$ denotes the $\log$ of total nominal labor income earned by households. $\kappa_{t}$ is the log of the nominal payoff from assets acquired before shocks are realized. Throughout, we suppress constant terms in the log linearization. $\zeta$ is human capital's share of wealth at the point of linearization. There is an analogous budget constraint for foreign households. As we shall see, the division of income between profits and returns to labor is irrelevant for our conclusions.

Under homothetic preferences, log aggregate consumption can be written as a function of consumption of an aggregate of Home goods and an aggregate of Foreign goods.

$$
c_{t}=\frac{1+\alpha}{2} c_{h, t}+\frac{1-\alpha}{2} c_{f, t}, \quad 0 \leq \alpha<1
$$

\footnotetext{
${ }^{7}$ We use a $t$ subscript, even in the static model, for two reasons. First, it allows for easy comparison to the dynamic model of Section III. Second, constant terms - terms that do not vary with the state-are distinguished by the lack of the $t$ subscript.
} 
Here, $(1+\alpha) / 2$ is the share of Home goods in nominal expenditures (at the point of approximation). When $\alpha>0$, there is home bias in consumption. Because the countries are of equal size, if preferences of Home and Foreign households were identical, consumption shares would equal 1/2. The Foreign household's consumption is given by

$$
c_{t}^{*}=\frac{1-\alpha}{2} c_{h, t}^{*}+\frac{1+\alpha}{2} c_{f, t}^{*} .
$$

Throughout, the * superscript pertains to variables related to Foreign households. The log of the consumer price indexes for Home and Foreign households are given by

$$
\begin{gathered}
p_{t}=\frac{1+\alpha}{2} p_{h, t}+\frac{1-\alpha}{2} p_{f, t} \text {, and } \\
p_{t}^{*}=\frac{1-\alpha}{2} p_{h, t}^{*}+\frac{1+\alpha}{2} p_{f, t}^{*} \text {, respectively. }
\end{gathered}
$$

$p_{h, t}$ and $p_{f, t}$ are the logs of price indexes, in Home currency, for Home consumption of the aggregates of Home and Foreign goods, respectively. $p_{h, t}^{*}$ and $p_{f, t}^{*}$ are defined analogously, and are expressed in Foreign currency terms 8

Denote the elasticity of substitution between the aggregates of Home and Foreign goods (at the point of approximation) by $\omega$. We will assume that elasticity is the same for both Home and Foreign households. Then, for example, (log) nominal demand for Home goods by Home households is given by $p_{h, t}+c_{h, t}=(1-\omega)\left(p_{h, t}-p_{t}\right)+$ $p_{t}+c_{t}$. Analogous equations hold for Home demand for the Foreign aggregate, and for Foreign demand for each aggregate.

In equilibrium, the total nominal demand for Home goods must equal the nominal revenue of Home firms. Nominal revenue for Home firms equals $\zeta h_{t}+(1-\zeta) \pi_{t}$ (because profits are defined as revenues less labor costs). Demand for Home goods comes from Home and Foreign households. Therefore, we can rewrite the budget constraint (1) as

$$
\begin{aligned}
p_{t}+c_{t}= & \frac{1+\alpha}{2}\left[(1-\omega)\left(p_{h, t}-p_{t}\right)+p_{t}+c_{t}\right] \\
& +\frac{1-\alpha}{2}\left[(1-\omega)\left(p_{h, t}^{*}-p_{t}^{*}\right)+s_{t}+p_{t}^{*}+c_{t}^{*}\right]+\kappa_{t} .
\end{aligned}
$$

\footnotetext{
${ }^{8}$ The model presented here assumes a symmetric home bias in consumption. However, our results do not depend on this assumption. The key point is that we linearize around a deterministic equilibrium with balanced trade, so Home expenditure on Foreign goods equals Foreign expenditure on Home goods at the point of approximation.
} 
The first term on the right-hand side of this equation represents total demand for Home goods from Home households, and the second term is demand for Home goods from Foreign households. Demand is expressed in nominal terms. Foreign demand is converted into Home currency using the spot exchange rate. $s_{t}$ is the log of the Home currency price of Foreign currency. The analogous condition for Foreign households, in terms of Foreign currency, is symmetric:

$$
\begin{aligned}
p_{t}^{*}+c_{t}^{*}= & \frac{1+\alpha}{2}\left[(1-\omega)\left(p_{f, t}^{*}-p_{t}^{*}\right)+p_{t}^{*}+c_{t}^{*}\right] \\
& +\frac{1-\alpha}{2}\left[(1-\omega)\left(p_{f, t}-p_{t}\right)-s_{t}+p_{t}+c_{t}\right]+\kappa_{t}^{*} .
\end{aligned}
$$

As noted previously, ex ante portfolios have zero net worth. Short positions are balanced by long positions: $\kappa_{t}+\kappa_{t}^{*}=0$, which can be verified by adding equations (6) and (7) and using the definitions of the price indexes, (4) and (5). It follows that payoffs from these portfolios have a zero sum across Home and Foreign households.

We can get relative Home to Foreign consumption by rearranging equations (4), (5), and (6):

$$
c_{t}-c_{t}^{*}=s_{t}+p_{t}^{*}-p_{t}+\frac{(1+\alpha)(\omega-1)}{2}\left(p_{f, t}-p_{h, t}+p_{f, t}^{*}-p_{h, t}^{*}\right)+\frac{2}{1-\alpha} \kappa_{t} .
$$

Equation (8) shows that relative consumption depends on the real exchange rate, $s_{t}+p_{t}^{*}-p_{t}$, the relative price of Foreign to Home goods in each country, and the asset payoffs. The real exchange rate is a function of the deviations from the law of one price for each good, $s_{t}+p_{f, t}^{*}-p_{f, t}$ and $s_{t}+p_{h, t}^{*}-p_{h, t}$, and the relative price of Foreign to Home goods in each country. We could say that relative consumption depends on the deviations from the law of one price, and relative prices within each country, and the asset payoffs. This demonstrates the important point that when households hold their equity endowment and cannot trade shares, relative consumption risk is transmitted through goods prices in equilibrium.

We do not measure relative risk strictly by looking at $c_{t}-c_{t}{ }^{*}$. For one thing, since Home and Foreign households consume different baskets, relative aggregate consumption may move over time, even if consumption of each type of goods is perfectly correlated across Home and Foreign households. In addition, Home and Foreign households may pay different prices for the same goods, so it may not be optimal for their consumption of each good to be perfectly correlated. Instead, as is well understood in the literature, optimal allocation equates the marginal utility of a "dollar" spent by Home households $\left(-\rho c_{t}-p_{t}\right)$ with the marginal utility of a "dollar" spent by Foreign households $\left(-\rho c_{t}{ }^{*}-s_{t}-p_{t}{ }^{*}\right)$, where we use the term "dollar" to denote a unit of Home's currency. Here, $\rho$ is the coefficient of relative risk aversion, evaluated at the point of linearization (where we are assuming utility is separable in aggregate consumption). This suggests we can measure deviations 
from efficient risk sharing by $c_{t}-c_{t}{ }^{*}-\left(s_{t}+p_{t}{ }^{*}-p_{t}\right) / \rho$. But it still follows that these deviations depend only on the real exchange rate and relative goods prices:

$$
\begin{aligned}
c_{t}- & c_{t}^{*}-\left(\frac{1}{\rho}\right)\left(s_{t}+p_{t}^{*}-p_{t}\right) \\
= & \left(1-\frac{1}{\rho}\right)\left(s_{t}+p_{t}^{*}-p_{t}\right)+\frac{(1+\alpha)(\omega-1)}{2}\left(p_{f, t}-p_{h, t}+p_{f, t}^{*}-p_{h, t}^{*}\right) \\
& +\frac{2}{1-\alpha} \kappa_{t} .
\end{aligned}
$$

When asset markets are complete (that is, when households can ex ante trade a complete set of nominal contingent claims) the equilibrium condition, $\left(-\rho c_{t}-p_{t}\right.$ $\left.=-\rho c_{t}^{*}-s_{t}-p_{t}^{*}\right)$, can be rearranged as

$$
c_{t}-c_{t}^{*}-\frac{1}{\rho}\left(s_{t}+p_{t}^{*}-p_{t}\right)=0 .
$$

In the special case of purchasing power parity (PPP) $\left(s_{t}+p_{t}^{*}-p_{t}=0\right)$, the condition implies equality of home and foreign consumption levels. ${ }^{-}$Equation (10) has been shown to be an equilibrium condition, under complete markets, in a wide variety of circumstances in which PPP does not hold: when there are nontraded goods, when consumption baskets are not identical, and when the law of one price is violated internationally.

Inspection of equation (9) shows that the complete markets allocation can be achieved if the payoffs from the assets are equal to

$$
\begin{aligned}
\kappa_{t}=\frac{\alpha-1}{2}[ & \left(1-\frac{1}{\rho}\right)\left(s_{t}+p_{t}^{*}-p_{t}\right) \\
& \left.+\frac{(1+\alpha)(\omega-1)}{2}\left(p_{f, t}-p_{h, t}+p_{f, t}^{*}-p_{h, t}^{*}\right)\right] .
\end{aligned}
$$

As in the Lucas (1982) model, households do not need to trade contingent claims to get these payoffs. For example, Home and Foreign households could trade assets ex ante whose payoffs were linear in the real exchange rate, $s_{t}+p_{t}^{*}-p_{t}$, relative prices in Home, $p_{f, t}-p_{h, t}$, and relative prices in Foreign, $p_{f, t}^{*}-p_{h, t}^{*}$. By taking the appropriate forward position in these hedges, Home households could get the asset payoff (11). By symmetry, Foreign households receive $-\kappa_{t}$. This portfolio allocation achieves optimal risk sharing, but foregoes trade in equities.

Many models assume the law of one price holds. In that case, $p_{f, t}-p_{h, t}=p_{f, t}^{*}-p_{h, t}^{*}$, and $s_{t}+p_{t}^{*}-p_{t}=\alpha\left(p_{f, t}-p_{h, t}\right)$. Equation (11) reduces to

$$
\kappa_{t}=\frac{\alpha-1}{2}\left[\left(1-\frac{1}{\rho}\right) \alpha+(1+\alpha)(\omega-1)\right]\left(p_{f, t}-p_{h, t}\right) .
$$

\footnotetext{
${ }^{9}$ Our two countries are symmetric ex ante, so they have equal ex ante wealth. In general, when PPP holds, consumption levels are equal, up to a constant multiple, across all states, under complete markets.
} 
In that type of model, full risk sharing could be achieved by trading only an instrument that hedges the terms of trade, $p_{f, t}-p_{h, t}$.

Realistically, there are failures of the law of one price. Moreover, markets are not available to hedge terms of trade or even real exchange rate risk explicitly. But when prices are sticky, the log of the real exchange rate and log of the terms of trade in each country are linear in the log of the nominal exchange rate. Households can achieve complete risk sharing with only trade in an exchange-rate hedge. Forward markets for foreign exchange do exist. Moreover, a synthetic forward position can be obtained by trading nominal bonds, or with swaps.

This conclusion holds as long as all nominal prices are set ex ante. However, it does not depend on the currency of price setting. Prices could all be set in the producer's currency (PCP). Or, prices facing consumers might be set ex ante in the local currency (LCP). Or, we might even have prices indexed to the exchange rate, as in Giancarlo Corsetti and Pesenti (2005) or Engel (2006).

We assume $p_{h, t}=0$, and $p_{f, t}^{*}=0$. These assumptions mean that the Home-currency price of home goods sold in the Home currency, and the Foreign-currency price of Foreign goods sold in the Foreign country are constant (independent of shocks) and normalized to one (in levels). We can assume partial pass-through for traded prices; $p_{f, t}=b s_{t}, p_{h, t}^{*}=-b s_{t}, 0 \leq b \leq 1 . b$ is the degree of indexing of consumer prices of imported goods to exchange rates. LCP corresponds to $b=0$, and PCP corresponds to $b=1$.

Under these assumptions, $s_{t}+p_{t}^{*}-p_{t}=[1-b(1-\alpha)] s_{t}$, and $p_{f, t}-p_{h, t}+p_{f, t}^{*}-p_{h, t}^{*}$ $=2 b s_{t}$. Substitute into equation (11) to get

$$
\kappa_{t}=\delta s_{t}, \quad \delta=\frac{\alpha-1}{2}\left\{\left(1-\frac{1}{\rho}\right)[1-b(1-\alpha)]+(1+\alpha)(\omega-1) b\right\} .
$$

If Home and Foreign agents can take a forward position in foreign exchange, they can achieve the complete-markets allocation. No trade in equities is required. A forward contract costs one unit of the Home currency. Under our assumptions of symmetry, we can normalize the forward price of foreign exchange to be unity, so the log of the forward rate is zero. If Home households purchase $\delta$ units of this hedge, they will achieve the payoff given in (13).

We have reached a dramatic conclusion. Complete hedging can be achieved without trade in equities. It is useful to review what we have assumed and what we have not assumed. We have assumed a one-period horizon, and that all nominal goods prices are fixed ex ante. These two assumptions are critical to the result. When goods prices can adjust, the nominal exchange rate cannot generally hedge relative price and real exchange rate risk. We will move on to an infinite-horizon model with price adjustment in Section III. There, trade in equities is necessary to replicate the complete markets equilibrium, and the equilibrium portfolio will not exhibit complete home bias. But we argue that there may be substantial home bias when a nominal exchange rate hedge is available. We have made other assumptions, such as the absence of physical capital, that are also crucial, and that we will not generalize in Section III. Indeed, the model we lay out explicitly in Sections II and III specializes the above model by assuming no home bias in preferences and local-currency pricing. 
The result we have obtained holds, as we have shown, whether price stickiness is of the PCP, LCP, or indexing form. We also have made no assumptions about labor markets. There could be a spot market in labor, with flexible wages, or households could have market power in labor markets, and nominal wages could be sticky. There could be bargaining between households and firms over revenues. We have not specified, at this stage, how revenues are split between firm owners and workers when there is no trade in equities.

We also have not specified the sources of shocks to the system. There can be real productivity shocks and nominal monetary shocks. These shocks could influence all of the variables in the system: exchange rates, labor income, profits, consumption, etc. It is important that we have assumed no preference shocks. If there were shocks that changed preferences for Home relative to Foreign goods, we would not be able to write relative revenues of Home/Foreign firms as a function only of relative prices and total expenditure. Homotheticity is also necessary for our results.

To restate our conclusion, when households in each country have complete ownership of their own firms (100 percent home bias in equity holdings), relative consumption risk is translated through relative prices. When there is full-price stickiness, the relative prices adjust only with changes in the nominal exchange rate. So, a forward position in foreign exchange can fully hedge risk.

But equation (10) presents a puzzle. When $\rho>1$, given our restrictions on parameters, we must have $\delta \leq 0$. That is, the optimal Foreign exchange hedge requires that Home agents are short in Foreign currency and long in Home currency, so that a Home appreciation (a decrease in $s_{t}$ ) has a positive payoff. It is well known that relationship (10) does not hold in the data. We do not see a strong positive correlation between Home relative to Foreign consumption and the real exchange rate. Our model suggests that it is because countries have not taken a sufficiently long net Foreign exchange position, not because their equity portfolios are insufficiently diversified.

Next, we fully specify a general equilibrium model in a static setting.

\section{A Simple Equilibrium Static Model}

In this section, we fully specify a static model that is a special case of the general (but not fully specified) model considered in Section I. There are two purposes for this section. First, the specification of the model is essentially the same as the dynamic model considered in Section III, but the economic forces are, perhaps, easier to understand. It serves as a bridge between Sections I and III. In particular, we are explicit about the microeconomic foundations of the model. We derive asset demands from first-order conditions and derive the equilibrium, and, we are explicit about the sources of shocks. Second, we derive asset demand equations that are familiar in the static setting - asset demands depend on variances and covariances of returns-but we interpret the moments in general equilibrium in terms of the underlying second moments of the shocks to the economy. This allows a different perspective on the conclusion that all international relative risk can be hedged with a forward position in foreign exchange.

In our model, households provide labor and own equity in firms. Firms use labor as the only input to produce a good monopolistically, and preset their prices in the 
consumers' currency. Markets are segmented so that only firms can export goods. All goods are tradable and perishable. We assume that, before the realization of shocks, only forward contracts in the foreign exchange and equities are traded.

We assume local currency pricing of goods. We observe in the data, at least for developed countries, that consumer prices are sticky in the consumers' currencies rather than in the producers' currencies. However, the assumption of currency of pricing is not important in determining the equity portfolio. In fact, we would have exactly the same equity portfolio when prices are preset in producers' currencies, even though the equilibrium number of forward contracts differs. 10

We consider two kinds of shocks: monetary and technology shocks (which may be correlated). The distribution of shocks is identical in Home and Foreign. The technical details of the model are laid out in Sections IIA and IIB. Section IIC derives the optimal portfolios and provides interpretation.

\section{A. Households}

Households in both countries have identical preferences over the consumption basket, the real money of the domestic country, and leisure. There are two stages to the household decision problem. In the first stage, households choose a portfolio position: shares of Home equities $\left(\gamma_{h}\right)$, shares of Foreign equities $\left(\gamma_{f}\right)$, and a forward position in foreign exchange $(\tilde{\delta})$. These are chosen before the resolution of uncertainty. After shocks are realized, households choose consumption, labor supply, and money balances to maximize

$$
\begin{gathered}
U\left(C_{t}, \frac{M_{t}}{P_{t}}, L_{t}\right)=\frac{1}{1-\rho} C_{t}^{1-\rho}+\chi \ln \left(\frac{M_{t}}{P_{t}}\right)-\frac{\eta}{1+\psi} L_{t}^{1+\psi}, \\
\rho>0, \chi>0, \psi \geq 0 \text {, and } \eta>0
\end{gathered}
$$

subject to the constraint

$$
P_{t} C_{t}+M_{t}=\gamma_{h} \Pi_{t}+\gamma_{f} S_{t} \Pi_{t}^{*}+W_{t} L_{t}+\tilde{\delta}\left(S_{t}-F_{t}\right)+\operatorname{Tr}_{t}
$$

$C_{t}$ denotes the consumption basket for Home; $M_{t}$ denotes Home money; $P_{t}$, the price index; and $L_{t}$, the labor supply. $C_{t}$ is a consumption basket of a representative Home household defined as

$$
C_{t} \equiv\left(\frac{1}{2}\right)^{1 /(\omega-1)}\left(C_{h, t}^{(\omega-1) / \omega}+C_{f, t}^{(\omega-1) / \omega}\right)^{\omega /(\omega-1)},
$$


where $\omega>0$ is the elasticity of substitution between Home produced goods and Foreign produced goods. $C_{h, t}$ is the consumption basket of Home produced goods and $C_{f, t}$ is that of Foreign produced goods:

$$
C_{h, t} \equiv\left[2^{1 / \lambda} \int_{0}^{1 / 2} C_{h, t}(i)^{(\lambda-1) / \lambda} d i\right]^{\lambda /(\lambda-1)}, C_{f, t} \equiv\left[2^{1 / \lambda} \int_{1 / 2}^{1} C_{f, t}(i)^{(\lambda-1) / \lambda} d i\right]^{\lambda /(\lambda-1)},
$$

where $\lambda$ denotes the elasticity of substitution among varieties, with $\lambda>1$. We can write the CPI as follows:

$$
P_{t} \equiv\left(\frac{1}{2}\right)^{1 /(1-\omega)}\left(P_{h, t}^{1-\omega}+P_{f, t}^{1-\omega}\right)^{1 /(1-\omega)},
$$

where

$$
P_{h, t} \equiv\left[2 \int_{0}^{1 / 2} P_{h, t}(i)^{1-\lambda} d i\right]^{1 /(1-\lambda)}, \quad P_{f, t} \equiv\left[2 \int_{1 / 2}^{1} P_{f, t}(i)^{1-\lambda} d i\right]^{1 /(1-\lambda)},
$$

where $P_{h, t}(i)$ is the price of Home goods $i$ sold at Home in terms of the Home currency, and $P_{f, t}(i)$ is the price of Foreign goods $i$ sold at Home in terms of the Home currency.

Home households receive the following: wages $\left(W_{t} L_{t}\right.$, where $W_{t}$ denotes the wage), dividends, transfers from the government $\left(\operatorname{Tr}_{t}\right)$, and the gains or losses from forward contracts. Equity dividends received by a Home household are given by

$$
\gamma_{h} \Pi_{t}+\gamma_{f} S_{t} \Pi_{t}^{*}
$$

where $\Pi_{t}$ is the profit (dividend) of Home firms, and $\Pi_{t}^{*}$ is that of Foreign firms in terms of the Foreign currency. ${ }^{11} S_{t}$ is the Home currency price of Foreign currency. Home and Foreign households trade forward contracts in the Foreign exchange. The forward rate, $F_{t}$, is known at the time the forward contract is entered into, prior to the realization of shocks. After the shocks are realized, the Home households receive $\tilde{\delta}\left(S_{t}-F_{t}\right)$ units of Home currency.

Foreign households have an analogous utility function for Foreign quantities and prices, which we will denote by superscript asterisks. Foreign prices are denominated in Foreign currency.

Prior to the realization of shocks, the households choose the portfolio position to maximize expected utility $\left(E_{t-1} U\left(C_{t}, M_{t} / P_{t}, L_{t}\right)\right) \frac{12}{12}$ subject to the constraint

$$
\gamma_{h}+\gamma_{f}=1
$$

Note that there is no constraint on the forward position, $\tilde{\delta}$. We assume that the ex ante distribution of shocks is identical between Home and Foreign. This assumption,

\footnotetext{
${ }^{11}$ Theoretically, profits can be negative in the case of a loss, but we have to assume that the profits of both Home firms and Foreign firms are positive to take logarithms.

${ }^{12}$ We use the notation that expectations are taken at time $t-1$ in this section, even though the model is static, for notational convenience, so that we can refer to some of the same equations that arise in the dynamic model.
} 
together with the assumptions of identical size and identical preferences, gives us an equilibrium in which the equity prices of Home and Foreign firms are the same prior to the realization of shocks 13 In our normalization, the representative household of each country is endowed with an ownership share of one of their own firms, but they may trade some of their shares with households in the other country, which implies constraint (20). Given the symmetry in the model, there is home bias in equity holdings when $\gamma_{f}<1 / 2$.

Given prices and the total consumption basket, $C_{t}$, the optimal consumption allocations are

$$
C_{h, t}=\frac{1}{2}\left(\frac{P_{h, t}}{P_{t}}\right)^{-\omega} C_{t}, \quad C_{f, t}=\frac{1}{2}\left(\frac{P_{f, t}}{P_{t}}\right)^{-\omega} C_{t},
$$

$$
C_{h, t}(i)=2\left(\frac{P_{h, t}(i)}{P_{h, t}}\right)^{-\lambda} C_{h, t}, \quad C_{f, t}(i)=2\left(\frac{P_{f, t}(i)}{P_{f, t}}\right)^{-\lambda} C_{f, t} .
$$

The remaining first-order conditions are

$$
\begin{gathered}
\frac{M_{t}}{P_{t}}=\chi C_{t}^{\rho}, \\
W_{t}=\frac{\eta}{\chi} M_{t} L_{t}^{\psi}, \\
E_{t-1}\left(S_{t} \frac{C_{t}^{-\rho}}{P_{t}}\right)=F_{t} E_{t-1}\left(\frac{C_{t}^{-\rho}}{P_{t}}\right), \\
E_{t-1}\left(\Pi_{t} \frac{C_{t}^{-\rho}}{P_{t}}\right)=E_{t-1}\left(S_{t} \Pi_{t}^{*} \frac{C_{t}^{-\rho}}{P_{t}}\right) .
\end{gathered}
$$

\section{B. Firms}

Firms engage in monopolistic competition as in Olivier Jean Blanchard and Nobuhiro Kiyotaki (1987). A firm in this economy monopolistically produces a specific good indexed by $i$ using a linear technology 14

$$
Y_{t}(i)=A_{t} L_{t}(i)
$$

${ }^{13}$ If prices are different, then one country is richer than the other ex ante, a situation that contradicts symmetry.

${ }^{14}$ Using a Cobb-Douglas technology with other fixed inputs will not change the result if the returns on the other factors belong to the equity holders. 
where $Y_{t}(i)$ is the production of firm $i, A_{t}$ is the country-specific technology parameter, and $L_{t}(i)$ is the labor input of firm $i$. Labor is assumed to be homogeneous, and to be supplied elastically. Home and Foreign markets are segmented, and only the producer can distribute its product. Firms set prices one period in advance in the consumers' currencies for each country. Firms in each country set prices so as to maximize their expected profits, taking other firms' prices as given, which is equivalent to taking the price level as given since each firm has measure zero on interval $[0,1]$.

Given the CES utility subfunction, the demand for Home good $i$ from the Home market denoted by $Y_{h, t}(i)$ is

$$
Y_{h, t}(i)=\left(\frac{P_{h, t}(i)}{P_{h, t}}\right)^{-\lambda}\left(\frac{P_{h, t}}{P_{t}}\right)^{-\omega} C_{t},
$$

while the demand for Home good $i$ from the Foreign market is

$$
Y_{h, t}(i)^{*}=\left(\frac{P_{h, t}^{*}(i)}{P_{h, t}^{*}}\right)^{-\lambda}\left(\frac{P_{h, t}^{*}}{P_{t}^{*}}\right)^{-\omega} C_{t}^{*}
$$

Firm $i$ 's profit maximization problem is

$$
\max _{P_{h, t}(i), P_{h, t}^{*}(i)} E_{t-1}\left\{\tilde{D}_{t}(i)\left[P_{h, t}(i) Y_{h, t}(i)+S_{t} P_{h, t}^{*}(i) Y_{h, t}^{*}(i)-\frac{W_{t}}{A_{t}}\left(Y_{h, t}(i)+Y_{h, t}^{*}(i)\right)\right]\right\},
$$

where $\tilde{D}_{t}(i)$ is the stochastic discount factor for the firm $i$. For example, if firms are owned by Home residents, it will be $C_{t}^{-\rho} / P_{t}$. However, because firms are not always domestically owned, we use a more general notation.

The optimal price of Home goods for the Home market is 15

$$
P_{h, t}=\frac{\lambda}{\lambda-1} \frac{E_{t-1}\left(\tilde{D}_{t} C_{t} \frac{W_{t}}{A_{t}}\right)}{E_{t-1}\left(\tilde{D}_{t} C_{t}\right)} .
$$

Similarly, the optimal price of Home goods for the Foreign market is

$$
P_{h, t}^{*}=\frac{\lambda}{\lambda-1} \frac{E_{t-1}\left(\tilde{D}_{t} C_{t}^{*} \frac{W_{t}}{A_{t}}\right)}{E_{t-1}\left(\tilde{D}_{t} C_{t}^{*} S_{t}\right)} .
$$

\footnotetext{
${ }^{15}$ We will omit index $i$ since Home firms are identical.
} 
Because firms are all alike, they will set the identical prices for each market.

The market clearing condition can be obtained by equating the output with the sum of the demands for Home goods:

$$
A_{t} L_{t}=\frac{1}{2}\left(\frac{P_{h, t}}{P_{t}}\right)^{-\omega} C_{t}+\frac{1}{2}\left(\frac{P_{h, t}^{*}}{P_{t}^{*}}\right)^{-\omega} C_{t}^{*} .
$$

Given these prices, we can calculate profits. Using the optimal consumption allocations, we can write the profits for the firms in each country in terms of the Home currency as

$$
\begin{gathered}
\Pi_{t}=\frac{1}{2} P_{h, t}\left(\frac{P_{h, t}}{P_{t}}\right)^{-\omega} C_{t}+\frac{1}{2} S_{t} P_{h, t}^{*}\left(\frac{P_{h, t}^{*}}{P_{t}^{*}}\right)^{-\omega} C_{t}^{*}-W_{t} L_{t}, \\
S_{t} \Pi_{t}^{*}=\frac{1}{2} S_{t} P_{f, t}^{*}\left(\frac{P_{f, t}^{*}}{P_{t}^{*}}\right)^{-\omega} C_{t}^{*}+\frac{1}{2} P_{f, t}\left(\frac{P_{f, t}}{P_{t}}\right)^{-\omega} C_{t}-S_{t} W_{t}^{*} L_{t}^{*} .
\end{gathered}
$$

Firms will pay out all of their profits as dividends.

We assume that $A_{t}$ and $A_{t}^{*}$ are drawn from identical lognormal distributions with $\operatorname{var}_{t-1}\left(\ln \left(A_{t}\right)\right)=\operatorname{var}_{t-1}\left(\ln \left(A_{t}^{*}\right)\right)=\sigma_{a}^{2}$, and $\operatorname{cov}_{t-1}\left(\ln A_{t,} \ln A_{t}^{*}\right)=\sigma_{a, a^{*}}$. We also assume that $M_{t}$ and $M_{t}^{*}$ are drawn from identical lognormal distributions with $\operatorname{var}_{t-1}\left(\ln \left(M_{t}\right)\right)$ $=\operatorname{var}_{t-1}\left(\ln \left(M_{t}^{*}\right)\right)=\sigma_{m}^{2}$, and $\operatorname{cov}_{t-1}\left(\ln M_{t}\right.$, $\left.\ln M_{t}^{*}\right)=\sigma_{m, m^{*}}$. We allow for correlation between monetary and technology shocks, as long as it is not perfect correlation.

The labor market is competitive, and the wage moves freely to equate demand and supply of labor after the shocks. The output of each good is determined by demand. Firms adjust output after the shocks to satisfy demand, holding prices constant. The money market is assumed to equilibrate, so money demand equals money supply.

\section{Solution of the Static Model}

An equilibrium in the static model satisfies equations (15) and (18)-(34), and their foreign counterparts. These 39 equations (one is redundant by Walras' Law) solve for $C_{t}, C_{h, t}, C_{f, t}, C_{h, t}(i), C_{f, t}(i), L_{t}, W_{t}, P_{t}, P_{h, t}, P_{f, t}, P_{h, t}(i), P_{h, t}^{*}(i), Y_{t}(i), Y_{h, t}(i)$, $Y_{h, t(i)}^{*}, \Pi_{t}, \gamma_{h}, \gamma_{f}$, and their foreign counterparts, and $\tilde{\delta}, F_{t}$, and $S_{t} 1.6$

We will not, in fact, solve for this equilibrium, but will, instead, solve the equilibrium for a set of equations that approximate these 39. We take first-order approximations to the budget constraint (15), the definitions of the consumption and price indexes (16)-(19), the equilibrium condition (32), and the definition of profits (33)-(34). Under our assumption that the driving variables are lognormally distributed, and with the log-linearization of these equations, we can solve equations (20)(31) exactly. By exactly solving the Euler equations (25)-(26), we have successfully integrated international portfolio choice into a sticky-price model.

\footnotetext{
${ }^{16}$ We have also implicitly assumed that there is a money market equilibrium condition, but we have not introduced separate notation for money demand and money supply, and that there is a forward market clearing condition which can be guaranteed by setting $\tilde{\delta}^{*}=F \tilde{\delta}$. By symmetry in the static model, $F$ equals one.
} 
Our focus is on the equilibrium portfolio choice of equity shares and forward foreign exchange position. We proceed, in this section, to construct the equilibrium solutions for these variables in an intuitive manner. We will first derive the portfolio demands for households, taking prices as given. With these in hand, we will use equilibrium conditions in goods, labor, and asset markets to derive the equilibrium portfolio positions.

We rely on ex ante symmetry in the derivations below. Lower-case letters refer to logs of their upper-case counterparts. We use "var" to denote variance, and "cov" covariance. ${ }^{17}$ We use the notation $\bar{x}=E\left(x_{t}\right)$. In the linearized equations below, we suppress the intercept terms for convenience.

Under log-normality, the household first-order condition (25) can be written as $-\rho \operatorname{cov}\left(c_{t}, s_{t}\right)+\operatorname{var}\left(s_{t}\right) / 2=0$, where we have used ex ante symmetry to give us $f_{t}$ $=0$, and $E\left(s_{t}\right)=0$. We can use similar steps, and recognize that symmetry implies that $\bar{\pi}=\bar{\pi}^{*}, \operatorname{var}\left(\pi_{t}\right)=\operatorname{var}\left(\pi_{t}^{*}\right)$, and $\operatorname{cov}\left(s_{t}, \pi_{t}\right)=-\operatorname{cov}\left(s_{t}, \pi_{t}^{*}\right)$, to derive from equation (26): $\rho \operatorname{cov}\left(c_{t}, \pi_{t}-\left(s_{t}+\pi_{t}^{*}\right)\right)-\operatorname{cov}\left(s_{t}, \pi_{t}-\left(s_{t}+\pi_{t}^{*}\right)\right) / 2=0$. We approximate the budget constraint (15), using condition (20) to arrive at the equation which corresponds to equation (1) for the fully-specified model:

$$
p_{t}+c_{t}=(1-\gamma)(1-\zeta) \pi_{t}+\gamma(1-\zeta)\left(s_{t}+\pi_{t}^{*}\right)+\zeta\left(w_{t}+l_{t}\right)+\delta s_{t},
$$

where $\zeta \equiv e^{\bar{w}+\bar{l}} /\left(e^{\bar{\pi}}+e^{\bar{w}+\bar{l}}\right), \delta \equiv \tilde{\delta} /\left(e^{\bar{\pi}}+e^{\bar{w}+\bar{l}}\right)$, and $\gamma \equiv \gamma_{f}$. Here, we have approximated the budget constraint around a point where $x_{t}=\bar{x}$ for $x_{t}=s_{t}, c_{t}, \pi_{t}, \pi_{t}^{*}, w_{t}, l_{t}$.

Using these equations, and recognizing that $p_{t}$ is predetermined, we solve for $\gamma$ and $\delta$ :

$$
\gamma=\frac{\operatorname{cov}\left(\pi_{t}-\beta_{\pi, s} s_{t}, \pi_{t}-\pi_{t}^{*}\right)}{\operatorname{var}\left(\pi_{t}-\pi_{t}^{*}-\beta_{\pi-\pi^{*}, s} s_{t}\right)}+\frac{\zeta}{1-\zeta} \frac{\operatorname{cov}\left(w_{t}+l_{t}-\beta_{w+l, s} s_{t}, \pi_{t}-\pi_{t}^{*}\right)}{\operatorname{var}\left(\pi_{t}-\pi_{t}^{*}-\beta_{\pi-\pi^{*}, s} s_{t}\right)}
$$

where we have used the notation $\beta_{x, s} \equiv \operatorname{cov}\left(x_{t}, s_{t}\right) / \operatorname{var}\left(s_{t}\right)$.

Consider expression (36). From the household's point of view, the equity position is determined by the covariances and variances of shocks to profits and labor income that are orthogonal to exchange rates. Any variance in the portfolio that is attributable to exchange rate changes is hedged through the forward position, so the equity position is determined only by those risks that are uncorrelated with exchange rate risk.

If the component of labor income that is orthogonal to exchange rates were uncorrelated with relative profits of Home and Foreign firms (or if labor's share were zero), the second term in equation (36) would drop out. Then the share $\gamma$ of equities held in Foreign firms would increase as Home profits (orthogonal to the exchange rate) have a higher covariance with relative Home and Foreign profits. Under our symmetry assumption, this term will equal $1 / 2$, so the portfolio would be balanced between Home and Foreign equities if only the first term mattered. 18 It is the second term of equation (36) that will determine home bias.

\footnotetext{
${ }^{17}$ We drop the $t-1$ subscript on expectations for the rest of this section.

${ }^{18}$ This claim can be verified by noting $\pi_{t}=\left(\pi_{t}+\pi_{t}^{*}\right) / 2+\left(\pi_{t}-\pi_{t}^{*}\right) / 2$, and that the covariance of $\pi_{t}+\pi_{t}^{*}$ with $\pi_{t}-\pi_{t}^{*}$ or $s_{t}$ is zero by symmetry.
} 
That term tells us that the share of Foreign equities will be larger the greater the covariance between the component of wage income that is orthogonal to exchange rates and Home profits relative to Foreign profits. If this covariance is positive, there will be anti-home bias $(\gamma>1 / 2)$, as in Baxter and Jermann (1997). In that case, returns to Home equities (compared to returns on Foreign equities) are positively correlated (conditional on the exchange rate) with labor income, so the variance of total income (returns to equities and human capital) is reduced by holding a relatively large share of Foreign equities. There is home bias when the covariance is negative. In that case, Home equities serve as a hedge against the component of labor income shocks that is orthogonal to exchange rates.

So far, to arrive at equation (36), we have only used the households' first-order conditions and budget constraints, along with the symmetry assumption and the assumption that nominal prices are fixed. Now we can bring in one more equation from the rest of the economy, the linearization of the profit equation for Home firms. We have from (33)

$$
(1-\zeta) \pi_{t}+\zeta\left(w_{t}+l_{t}\right)=c_{t}^{W}+\frac{1}{2} s_{t},
$$

where $c_{t}^{W}=\left(c_{t}+c_{t}^{*}\right) / 219$

Taking covariances with $\pi_{t}-\pi_{t}^{*}$ on both sides of equation (37), we get

$$
\operatorname{cov}\left(\pi_{t}+\frac{\zeta}{1-\zeta}\left(w_{t}+l_{t}\right), \pi_{t}-\pi_{t}^{*}\right)=\frac{1}{2(1-\zeta)} \operatorname{cov}\left(s_{t}, \pi_{t}-\pi_{t}^{*}\right)
$$

where we have used symmetry to infer that $\operatorname{cov}\left(c_{t}^{W}, \pi_{t}-\pi_{t}^{*}\right)=0$. Also,

$$
\operatorname{cov}\left(\pi_{t}+\frac{\zeta}{1-\zeta}\left(w_{t}+l_{t}\right), s_{t}\right)=\frac{1}{2(1-\zeta)} \operatorname{var}\left(s_{t}\right)
$$

using symmetry to infer that $\operatorname{cov}\left(c_{t}^{W}, s_{t}\right)=0$. Dividing through by $\operatorname{var}\left(s_{t}\right)$, we can write

$$
\beta_{\pi, s}+\frac{\zeta}{1-\zeta} \beta_{w+l, s}=\frac{1}{2(1-\zeta)} .
$$

Substitute these relations into the right-hand side of (36) to derive $\gamma=0$, the result is that there is full home bias in the equity portfolio. We can then get the equilibrium value of $\delta$, when $\gamma=0$ :

$$
\delta=-\frac{1}{2}+\frac{1}{2 \rho}
$$

\footnotetext{
${ }^{19}$ In deriving (37), we use symmetry to get $\bar{c}=\bar{c}^{*}$ and $p_{t}=p_{t}^{*}$. The Appendix (which is available on request) shows that $p_{h t}-p_{t}=0$, which we have used to derive (37).
} 
This is the special case of equation (13) when pass-through is zero $(b=0)$, and when there is no home bias in preferences over goods $(\alpha=0)$.

In Section I, we demonstrated that the complete markets allocation would obtain if residents in each country retained ownership of their own firms, with the appropriate exchange-rate hedging instrument in place. In this section, we have derived the optimal allocations from the first-order conditions and market-clearing conditions, and we confirm that, in equilibrium, $\gamma=0$. It, of course, follows, since the loglinearized model of this section is a special case of the model of Section I, that the complete-markets equilibrium condition (10) will hold here. 20

Here, we can get some further intuition for why complete home bias in equity holdings, $\gamma=0$, is optimal when households can hedge exchange rate risk. When there is complete home bias, from the budget constraint (35), we find

$$
p_{t}+c_{t}=(1-\zeta) \pi_{t}+\zeta\left(w_{t}+l_{t}\right)+\delta s_{t} .
$$

Since prices are set in advance, consumption varies only when there are changes in Home firm revenues, $(1-\zeta) \pi_{t}+\zeta\left(w_{t}+l_{t}\right)$, or changes in the returns to the forward position, $\delta s_{t}$. Conditioning on the exchange rate (whose risk is hedged through forward contracts), there is no diversifiable consumption risk under this solution of complete home bias. Equation (37) tells us that the revenue of the Home firm, $(1-\zeta) \pi_{t}+\zeta\left(w_{t}+l_{t}\right)$, is determined by world consumption and the exchange rate (which helps determine demand for Home goods relative to Foreign goods), $c_{t}^{W}+s_{t} / 2$, so, after hedging the exchange rate risk, Home revenues depend only on variation in world consumption, $c_{t}^{W}$, which is risk that cannot be hedged. The solution of complete home bias, along with the appropriate hedge in Foreign exchange markets, eliminates all idiosyncratic risk.

The key point is this-Home labor income and profits for the Home firm (and analogously for Foreign) are negatively correlated conditioning on the exchange rate. By the phrase "conditioning on the exchange rate," we mean for a given exchange rate or holding the exchange rate constant. The availability of the forward market in foreign exchange allows households to hedge exchange rate risk. So the risk from profits and wage income that is relevant for households is the risk conditional on the exchange rate. For a given exchange rate, Home profits hedge Home labor income risk.

It is instructive to consider a particular shock. Suppose there is a positive home productivity shock. First, suppose there is no money supply reaction to this shock. Our LCP model has the special feature that $c_{t}^{W}+s_{t} / 2$ is not affected directly by the productivity shock. Output and revenue are demand-determined in a sticky-price model. In this case, the productivity shock leads to an increase in Home profits, $\pi_{t}$, and a reduction in Home wage income, $w_{t}+l_{t}$, that exactly offset each other. When there is an increase in productivity, firms' revenue is unchanged, so firms simply economize on labor. If Home households hold all of the claims to Home profits,

\footnotetext{
${ }^{20}$ In setting up the firms' problem, we did not specify the discount factor used by firms to evaluate profits. But when markets are effectively complete, the discount factor of Home and Foreign firms are equal to each other and equal to the household discount factor.
} 
the shock to their wage income is exactly hedged by the offsetting effect on profit income.

But this conclusion, that complete home bias is optimal, does not depend on the property of the LCP model that $c_{t}^{W}+s_{t} / 2$ is not directly influenced by the productivity shock. Indeed, suppose the monetary policy reaction function was such that the Home money supply increases when there is a positive Home productivity shock. Then $c_{t}^{W}$ and $s_{t}$ would both increase. But that does not change the conclusion that complete home bias in equity holdings is optimal. The shock to $c_{t}^{W}$ is not diversifiable. There will be an increase in revenue of Home firms relative to Foreign firms because of the depreciation of the Home currency, but that is fully hedged through the household's forward position. There is no diversifiable risk that the Home household can hedge by holding Foreign equities.

We have derived the complete home bias result using the nominal price stickiness assumption, the definition of Home profits, the budget constraint of Home households, and the two first-order conditions (25) and (26) that pertain to asset choice. The derivations in this subsection all arise from equations from the approximated versions of the two first-order conditions for asset choice, the household budget constraint, and the definition of firm profits. In performing the approximations, we have used the fact that goods prices are preset. As we noted at the end of Section I, the home bias result is robust to alternative assumptions. For example, the result does not depend on money demand arising from real balances in the utility function. Other specifications that maintain equations (25) and (26) will deliver the same result. The result does not depend on the assumptions about monetary policy. In particular, we emphasize that our result does not depend on any assumption about the correlation of money shocks and productivity shocks. It may be that money supplies respond contemporaneously to technology shocks. That policy affects the overall responses of employment and wages to technology shocks, but it does not affect the equity portfolio or the position in the forward market. The result also does not depend on our specification of the labor market as competitive with flexible wages. For example, a sticky-wage model in which employment was demand determined would not alter the conditions that we used in the derivation of the home bias result. As we have noted above, when the portfolio exhibits complete home bias in equities, and exchange rate changes are hedged, there is no idiosyncratic risk to income for households, so all consumption risk is eliminated.

The model of this section has special features relative to the more general model presented in Section I. The assumption of local currency pricing means that relative goods prices internally are not affected by shocks, because they are set ex ante. The real exchange rate shocks, in turn, reflect only deviations from the law of one price (which holds ex ante). Under LCP, when expressed in a common currency, revenues of Home and Foreign firms are perfectly correlated, as is apparent from equation (37). But the complete home bias in equities does not depend on these particular aspects of the LCP model.

When $\rho>1$, we find $\delta<0$. A depreciation of Home's currency reduces Home's wealth through the exchange-rate hedge. That corresponds to the situation in which a country's net position in nominal assets is short in foreign currency. This pattern is not consistent with US patterns, for example, and so we cannot understand the home 
bias in equity holdings among US households by appealing to the exchange-rate hedge discussed in this model. Intuitively, when the currency depreciates, revenue from Home firms increases in Home currency terms. From (37), a 1 percent depreciation leads to a 0.5 percent increase in Home revenues. With complete home bias in equity holdings, that increases Home consumption by 0.5 percent. Symmetrically, Foreign consumption falls 0.5 percent, so Home relative to Foreign consumption rises 1 percent. But from (10), under the optimal exchange rate hedge, Home relative to Foreign consumption should rise only $1 / \rho$ percent. Hence, Home needs to short foreign currency when $\rho>1$. In this static setting, even if we allowed for partial pass-through and home bias in preferences, equation (13) tells us that under plausible parameterizations $(\rho>1, \omega \geq 1)$, Home should still be short in Foreign currency.

We emphasize that while we have shown that there is an equilibrium with $\gamma=0$, we have not shown it is the only portfolio equilibrium. However, the portfolio choice model is fairly standard when the model is linearized, and it is easy to see that this equilibrium is unique as long as there are two independent sources of shocks that affect returns on equities and the foreign exchange hedge. Note that using the firstorder condition for money holdings (23), and the complete-markets equilibrium condition (10), we find $s_{t}=m_{t}-m_{t}^{*}$. The exchange rate depends only on relative money supplies. However, we allow for money supplies to be set endogenously in response to technology shocks. The key assumption, however, is that relative money supplies cannot be perfectly correlated with relative productivity shocks, there must be some independent monetary variation. Otherwise, the return on the foreign exchange hedge and on the equity portfolio would be perfectly correlated, and the optimal portfolio would be indeterminate.

\section{Dynamic Model}

In this section, we build an infinite-horizon model, which allows us to examine the effects of persistent technology shocks and different degrees of price stickiness. Most of the assumptions are the same as in the static model. As we have explained, once prices can adjust, the forward exchange rate position cannot fully hedge international risk.

The price-setting rule is modified as follows. A fraction $\tau$ of firms in each country set prices in advance, and the rest of the firms can adjust their prices in each period, after the realization of shocks. This approach allows us to study the portfolio allocation with or without sticky prices, and we can learn how different degrees of price stickiness affect the portfolio. There are different types of firms in each country, but we assume the equities of all firms in each country are bundled together.

We address two important questions here. First, does price stickiness matter much for international portfolio choice? In a world with temporary price stickiness and persistent productivity shocks, one might expect the answer to be no. But we will show that, in fact, a small amount of price stickiness may matter. Second, how do persistent shocks affect the optimal portfolio? In a flexible price setting, the optimal portfolio is more foreign skewed than it is in the classic endowment economy case, as shown in Baxter and Jermann (1997). This effect decreases the degree of home 
bias in our model. In the dynamic model, when the elasticity of substitution between Home and Foreign goods is more than unity $(\omega>1)$, the optimal Home portfolio should be less home biased than it is in the static model because households must take into account the future, after prices have been adjusted. Nominal exchange-rate hedging matters for the short run when nominal prices are sticky, but cannot offer any real hedge in the long run when nominal prices adjust.

We have shown that we can integrate international portfolio choice into a monetary model by solving the Euler equations as discussed in the static model. Our model exhibits stationarity in the linearized economy by replicating the real-side allocations of a model with a full set of nominal contingent claims, although in our model, we have only equities and forward contacts. As shown in the Appendix, Home and Foreign equities and forward contracts span the linear space generated by relative shocks in the linearized economy.

Sections IIIA and IIIB lay out the technical details of the model. The solution is presented and analyzed in Section IIIC. In Section IIID, we substitute some numerical values into our solutions to get an appreciation for the quantitative values of the portfolios implied by the model.

\section{A. Household Problem}

Home households maximize their expected utility:

$$
\max E_{0} \sum_{t=0}^{\infty} \beta^{t} U\left(C_{t}, \frac{M_{t}}{P_{t}}, L_{t}\right),
$$

subject to the following budget constraint:

$$
\begin{gathered}
P_{t} C_{t}+M_{t}+Q_{t} \gamma_{h, t+1}+S_{t} Q_{t}^{*} \gamma_{f, t+1} \\
=\gamma_{h, t}\left(Q_{t}+\Pi_{t}\right)+\gamma_{f, t} S_{t}\left(Q_{t}^{*}+\Pi_{t}^{*}\right)+\left(S_{t}-F_{t}\right) \tilde{\delta}_{t}+W_{t} L_{t}+M_{t-1}+\operatorname{Tr}_{t},
\end{gathered}
$$

where $Q_{t}\left(Q_{t}^{*}\right)$ denotes the price of Home (Foreign) equities. The utility function and consumption baskets are the same as in the static model. Households enter time $t$ with money $M_{t-1}$, equities $\left(\gamma_{h, t}, \gamma_{f, t}\right)$, and forward contracts $\tilde{\delta}_{t}$. After the realization of shocks, households choose the consumption level, real money balances, and labor supply. The dividends from firms are paid at time $t$, and households get the payoff from the forward contract. They receive the transfer from the government as well. Finally, the households choose forward contracts $\tilde{\delta}_{t+1}$ and equity holdings $\gamma_{h, t+1}$, $\gamma_{f, t+1}$, which determine the dividends households receive at time $t+1$.

Our assumptions on consumption, asset acquisition, etc., follow exactly the standard presentation of the nonstochastic dynamic model (see, for example, Obstfeld and Kenneth S. Rogoff 1996), with one exception. We assume, as in the static model, that households can take a forward position in foreign exchange. Making a contract to buy Foreign exchange forward next period, of course, is equivalent to buying a nominal (nonstate-contingent) bond denominated in the Foreign currency and shorting a 
nominal bond denominated in the Home currency. We could have introduced nominal bonds denominated in each currency separately into the model, rather than forward contracts. However, that would add nothing to our presentation. We shall see below that the (linearized) model, with equities and forward contracts, reproduces the allocation that would be achieved with trade in a complete set of nominal statecontingent bonds. If we introduced nonstate-contingent nominal bonds instead of forward contracts, the position held by each household would reproduce their position in the forward market.

The first-order conditions for the households are

$$
\begin{gathered}
\frac{\chi}{M_{t}}=\frac{C_{t}^{-\rho}}{P_{t}}-E_{t} \beta \frac{C_{t+1}^{-\rho}}{P_{t+1}}, \\
\eta L_{t}^{\psi}=\frac{C_{t}^{-\rho}}{P_{t}} W_{t}, \\
E_{t-1}\left(\frac{C_{t}^{-\rho}}{P_{t}} S_{t}\right)=F_{t} E_{t-1}\left(\frac{C_{t}^{-\rho}}{P_{t}}\right), \\
\frac{C_{t-1}^{-\rho}}{P_{t-1}} Q_{t-1}=E_{t-1}\left(\beta \frac{C_{t}^{-\rho}}{P_{t}}\left(Q_{t}+\Pi_{t}\right)\right), \\
\frac{C_{t-1}^{-\rho} S_{t-1} Q_{t-1}^{*}}{P_{t-1}}=E_{t-1}\left(\beta \frac{C_{t}^{-\rho}}{P_{t}} S_{t}\left(Q_{t}^{*}+\Pi_{t}^{*}\right)\right) .
\end{gathered}
$$

First, let $D_{t, t+s} \equiv\left(C_{t+s}^{-\rho} / P_{t+s}\right) /\left(C_{t}^{-\rho} / P_{t}\right)$. The no-bubble solution for equity prices implies that

$$
Q_{t}=\sum_{s=1}^{\infty} E_{t} \beta^{s} D_{t, t+s} \Pi_{t+s}, \quad S_{t} Q_{t}^{*}=\sum_{s=1}^{\infty} E_{t} \beta^{s} D_{t, t+s} S_{t+s} \Pi_{t+s}^{*} .
$$

Let

$$
\begin{gathered}
V_{t} \equiv \gamma_{h, t+1} Q_{t}+\gamma_{f, t+1} S_{t} Q_{t}^{*}, \\
H_{t} \equiv \sum_{s=1}^{\infty} \beta^{s} E_{t} D_{t, t+s} W_{t+s} L_{t+s}, \\
R_{t} \equiv \frac{\beta\left(Q_{t}+\Pi_{t}\right)}{Q_{t-1}}, \\
R_{t}^{H} \equiv \frac{\beta\left(H_{t}+W_{t} L_{t}\right)}{H_{t-1}},
\end{gathered}
$$




$$
\gamma_{t+1} \equiv \frac{\gamma_{f, t+1} S_{t} Q_{t}^{*}}{V_{t}}=1-\frac{\gamma_{h, t+1} Q_{t}}{V_{t}}
$$

These are, respectively, financial wealth, human capital, the rate of return on financial wealth and human capital (each multiplied by the utility discount factor for algebraic convenience), and the share of foreign equity in equity portfolio.

We can rewrite the budget constraint (41) for time $t$ :

$$
\begin{aligned}
P_{t} C_{t}+V_{t}+H_{t}= & V_{t-1}\left(1-\gamma_{t}\right) \beta^{-1} R_{t}+V_{t-1} \gamma_{t} \beta^{-1} \frac{S_{t}}{S_{t-1}} R_{t}^{*} \\
& +H_{t-1} \beta^{-1} R_{t}^{H}+\tilde{\delta}_{t}\left(S_{t}-F_{t}\right) .
\end{aligned}
$$

We will assume, below, a process for the money supply in which $E_{t}\left(M_{t+1}^{-1}\right)=M_{t}^{-1}$. We note this now because, under this assumption, the first-order condition (42) can be simplified directly to get

$$
\frac{C_{t}^{-\rho}}{P_{t}}=\chi M_{t}^{-1}+E_{t} \beta \frac{C_{t+1}^{-\rho}}{P_{t+1}}=\frac{\chi}{1-\beta} M_{t}^{-1} .
$$

It follows from this that $D_{t, t+s}=M_{t} / M_{t+s}$. The first-order conditions for equity holdings, (45) and (46), can be summarized as

$$
E_{t-1}\left(\frac{M_{t-1}}{M_{t}} R_{t}\right)=E_{t-1}\left(\frac{M_{t-1}}{M_{t}} \frac{S_{t}}{S_{t-1}} R_{t}^{*}\right)=1
$$

\section{B. Firms}

Firms use the same linear technology as in the previous section. We have two types of firms in each country. A fraction $\tau$ of firms set the price in advance, and the rest set the price after the realization of shocks. The profit maximization problem of the Home firm with price flexibility is

$$
\max P_{h, t}(i) Y_{h, t}(i)+S_{t} P_{h, t}^{*}(i) Y_{h, t}^{*}(i)-\left(\frac{W_{t}}{A_{t}}\right)\left[Y_{h, t}(i)+Y_{h, t}^{*}(i)\right] .
$$

Because $Y_{h, t}(i)$ is not a function of $P_{h, t}^{*}(i)$, and $Y_{h, t}^{*}(i)$ is not a function of $P_{h, t}(i)$, the problem is easy to solve:

$$
P_{h, t}(i)=\frac{\lambda}{\lambda-1} \frac{W_{t}}{A_{t}} \equiv P_{f l e x, h, t}, \quad P_{h, t}^{*}(i)=\frac{\lambda}{\lambda-1} \frac{W_{t}}{A_{t} S_{t}} \equiv P_{\text {flex }, h, t}^{*},
$$

where $P_{f l e x, h, t}$ is the optimal price for the Home market of the Home goods produced by the firms that can adjust prices after they observe shocks. $P_{\text {flex,h,t }}^{*}$ is the optimal price for the Foreign market. 
The other optimal prices are

$$
\begin{aligned}
& P_{\text {preset }, h, t} \equiv \frac{\lambda}{\lambda-1} \frac{E_{t-1}\left[\tilde{D}_{t} \frac{W_{t}}{A_{t}}\left(\frac{1}{P_{h, t}}\right)^{-\lambda}\left(\frac{P_{h, t}}{P_{t}}\right)^{-\omega} C_{t}\right]}{E_{t-1}\left[\tilde{D}_{t}\left(\frac{1}{P_{h, t}}\right)^{-\lambda}\left(\frac{P_{h, t}}{P_{t}}\right)^{-\omega} C_{t}\right]}, \\
& P_{\text {preset }, h, t}^{*} \equiv \frac{\lambda}{\lambda-1} \frac{E_{t-1}\left[\tilde{D}_{t} \frac{W_{t}}{A_{t}}\left(\frac{1}{P_{h, t}^{*}}\right)^{-\lambda}\left(\frac{P_{h, t}^{*}}{P_{t}^{*}}\right)^{-\omega} C_{t}^{*}\right]}{E_{t-1}\left[\tilde{D}_{t}\left(\frac{1}{P_{h, t}^{*}}\right)^{-\lambda}\left(\frac{P_{h, t}^{*}}{P_{t}^{*}}\right)^{-\omega} C_{t}^{*}\right]},
\end{aligned}
$$

where $\tilde{D}$ is the stochastic discount factor, and $P_{\text {preset, } h, t}$ is the optimal price for the Home market at time $t$ of the goods produced by the firms that set prices in advance. Now, we can rewrite the price indexes as follows:

$$
\begin{gathered}
P_{h, t}=\left[(1-\tau) P_{\text {flex }, h, t}^{1-\lambda}+\tau P_{\text {preset }, h, t}^{1-\lambda}\right]^{1 /(1-\lambda)}, \\
P_{f, t}=\left[(1-\tau) P_{\text {flex }, f, t}^{1-\lambda}+\tau P_{\text {preset }, f, t}^{1-\lambda}\right]^{1 /(1-\lambda)} .
\end{gathered}
$$

Since we have CES sub-utility functions, the market clearing condition can be obtained by equating the output with the sum of the demands for Home goods:

$$
A_{t} L_{t}=\frac{1}{2}\left(\frac{P_{h, t}}{P_{t}}\right)^{-\omega} C_{t}+\frac{1}{2}\left(\frac{P_{h, t}^{*}}{P_{t}^{*}}\right)^{-\omega} C_{t}^{*} .
$$

While flexible-price firms will have higher profit than preset-price firms in general, CES sub-utility makes the aggregate profit of each country the same as before:

$$
\begin{gathered}
\Pi_{t}=\frac{1}{2} P_{h, t}\left(\frac{P_{h, t}}{P_{t}}\right)^{-\omega} C_{t}+\frac{1}{2} S_{t} P_{h, t}^{*}\left(\frac{P_{h, t}^{*}}{P_{t}^{*}}\right)^{-\omega} C_{t}^{*}-W_{t} L_{t}, \\
S_{t} \Pi_{t}^{*}=\frac{1}{2} S_{t} P_{f, t}^{*}\left(\frac{P_{f, t}^{*}}{P_{t}^{*}}\right)^{-\omega} C_{t}^{*}+\frac{1}{2} P_{f, t}\left(\frac{P_{f, t}}{P_{t}}\right)^{-\omega} C_{t}-S_{t} W_{t}^{*} L_{t}^{*} .
\end{gathered}
$$

We assume that

$$
\begin{gathered}
m_{t+1}=m_{t}+\nu_{t+1}^{m}, \quad m_{t+1}^{*}=m_{t}^{*}+\nu_{t+1}^{m^{*}}, \\
a_{t+1}^{W}=\vartheta_{W} a_{t}^{W}+\nu_{t+1}^{W}, \quad a_{t+1}^{R}=\vartheta_{R} a_{t}^{R}+\nu_{t+1}^{R},
\end{gathered}
$$


where $\vartheta_{W} \in[0,1], \vartheta_{R} \in[0,1)$ are degrees of persistence in world and relative technology levels, and where the vector $\boldsymbol{\nu}_{t}^{x}\left(x=m, m^{*}, W, R\right)$ is independently and identically distributed. We denote $\ln \left(X_{t}\right)$ as $x_{t}$, the world variables as $x_{t}^{W}=(1 / 2) x_{t}+(1 / 2) x_{t}^{*}$, and the relative variables as $x_{t}^{R}=x_{t}-x_{t}^{*}$. We assume $E v_{t+1}^{m}=E v_{t+1}^{m^{*}}=(1 / 2) \sigma_{m}^{2}$, so that $E_{t}\left(M_{t+1}^{-1}\right)=M_{t}^{-1}$, as mentioned above. We also assume $\operatorname{var}\left(v^{m}\right)=\operatorname{var}\left(v^{m *}\right)=\sigma_{m}^{2}$, and $\operatorname{cov}\left(v^{m}, v^{m *}\right)=\sigma_{m, m^{*}}, \operatorname{var}\left(v^{W}\right)=\sigma_{m}^{2}, \operatorname{var}\left(v^{R}\right)=\sigma_{R}^{2}$, and $\operatorname{cov}\left(v^{W}, v^{R}\right)=0$. We assume initial symmetry between Home and Foreign. That is, $a_{0}^{R}=0$, and $m_{0}^{R}=0$.

Note, in particular, that we have not made any assumptions about the correlation of monetary shocks and productivity shocks. As long as there is some independent component to the money shocks - that is, as long as the correlation between money and productivity shocks lies on the interval $(-1,1)$ - our results go through. In particular, our specification allows for an interpretation in which technology shocks, $\nu_{t+1}^{W}$ and $\nu_{t+1}^{R}$, are structural, and monetary shocks respond contemporaneously to technology shocks. For example, $\nu_{t+1}^{m} \equiv \varepsilon_{t+1}^{m}+\xi^{W} \nu_{t+1}^{w}+\xi^{R} \nu_{t+1}^{R}$ and $\nu_{t+1}^{m^{*}} \equiv \varepsilon_{t+1}^{m^{*}}+$ $\xi^{W} \nu_{t+1}^{w}-\xi^{R} \nu_{t+1}^{R}$, where $\varepsilon_{t+1}^{m}$ and $\varepsilon_{t+1}^{m^{*}}$ are structural monetary shocks.

\section{Solution of the Dynamic Model}

To solve the model, we use approximations similar to those in the static model. The Appendix presents the solution to the model. There, the equilibrium is defined and solutions for all the endogenous variables are given. It shows that the equilibrium conditions are satisfied for those solutions. Here, we discuss the salient features of the solution.

An important feature of the solution is that we are able to replicate the allocation achieved when a full set of state-contingent nominal bonds are traded in the linearly approximated model. We have two kinds of assets (equities and forward currency contracts) that span the space generated by $a_{t}^{R}$ and $m_{t}^{R}$. In that case, we have

$$
\rho\left(c_{t}-c_{t}^{*}\right)=s_{t}+p_{t}^{*}-p_{t} .
$$

This equation, which rewrites (10) for convenience, is the familiar condition that arises when there is a full set of contingent claims, but in which consumer price levels are not equal. 21

We show, in the Appendix, that $\delta_{t}$, the forward position in foreign exchange, and $\gamma_{t}$, the share of Foreign equities held in the Home portfolio, are constant over time and given by

$$
\begin{gathered}
\delta \equiv \delta_{t}=\frac{1}{2}\left(\frac{1}{\rho}-1\right) \tau, \\
\gamma \equiv \gamma_{t}=\gamma_{t}^{*}=\frac{1}{2(1-\zeta)} \frac{\Lambda}{\Omega+\Lambda},
\end{gathered}
$$

\footnotetext{
${ }^{21}$ There is a parallel to Baxter, Jermann, and King (1998). That paper hypothesizes that the portfolio choice (in a flexible-price model with nontraded goods) will replicate the complete market allocations. They make use of that conjecture in deriving the portfolios, then verify the conjecture.
} 
where

$$
\Lambda \equiv(\psi+1)(\omega-1)\left[\frac{1-\tau}{1+\omega(1-\tau) \psi}+\frac{1}{1+\omega \psi} \frac{\beta \vartheta_{R}}{1-\beta \vartheta_{R}}\right]
$$

and

$$
\Omega \equiv \frac{\zeta}{1-\zeta} \frac{(\psi+1) \tau}{1+\omega(1-\tau) \psi}
$$

Our formula for the optimal share can be written as $\gamma=\gamma^{F L E X} \Lambda /(\Lambda+\Omega)$, where $\gamma^{F L E X}$ is the share of foreign assets in the portfolio when prices are fully flexible. 22

The share of the equity portfolio held in foreign assets, $\gamma$, is increasing in $\Lambda$ and decreasing in $\Omega$. In order to have home bias, or $\gamma<1 / 2$, we need 23

$$
\frac{1-\omega(1-\tau)}{1+\omega(1-\tau) \psi}-\frac{\omega-1}{1+\omega \psi} \frac{\beta \vartheta_{R}}{1-\beta \vartheta_{R}}>0
$$

Notice that the condition (69) does not depend on $\rho$ or $\zeta$, while $\zeta$ determines the degree of home bias. There are intuitive explanations for how most of these parameters affect foreign equity demand.

As labor's share, $\zeta$, rises, $\gamma$ falls when there is home bias, and rises when there is anti-home bias. The intuition is straightforward given our discussion above. When the short-run effects of productivity shocks that lead to a negative covariance of Home profits and labor income (conditional on the exchange rate) are sufficiently large that there is home bias, the home bias is amplified the larger is labor's share. The benefits from hedging labor income risk are greater when labor's share is greater. But when the long-run effects dominate, and returns to human capital are hedged by having a foreign-equity bias, the effect is, again, amplified the larger labor's share.

$\beta \vartheta_{R}$ is, in a sense, a measure of the weight the future receives in the portfolio allocation decision. $\beta \vartheta_{R}$ is large when households place a high weight on the future, and when the relative productivity shocks have a very persistent influence. In the extreme case, when all prices are sticky $(\tau=1)$, and the future does not matter $\left(\beta \vartheta_{R}=0\right)$, there is complete home bias $(\gamma=0)$. This is just the static model we examined previously that assumed full price stickiness and placed no weight on the future.

On the other hand, if all goods prices were flexible, $\tau=0$, then the optimal equity portfolio is $\gamma=1 /[2(1-\zeta)]>1 / 2$. This outcome is similar to the theoretical result obtained by Baxter and Jermann (1997) — “the international diversification puzzle is worse than you think."

\footnotetext{
${ }^{22}$ When $\omega=1$, the flexible price portfolio is indeterminate. The formula for $\gamma$ shows this indeterminacy when $\omega=1$ and $\tau=0$.

${ }^{23}$ We omit the case in which the denominator in equation (68) is nonpositive. This case can happen only if the price is very flexible, and $\omega \leq 1$.
} 
$\gamma$ is decreasing in $\tau$, when $\omega>1$. Increasing price stickiness leads to greater home bias in equity holdings, which makes sense given our discussion of how the Foreign exchange rate hedges risk when prices are sticky.

When $\omega>1$, an increase in $\beta \vartheta_{R}$ leads to an increase in $\Lambda$, which implies a greater share of Foreign equities in the Home household's portfolio. In short, the more the future "matters," the larger the share of Foreign equities. In the limit, as $\beta \vartheta_{R} \rightarrow 1$, the portfolio approaches the flexible price value, $\gamma=1 /[2(1-\zeta)]$. On the other hand, as $\beta \vartheta_{R} \rightarrow 0$, the portfolio approaches

$$
\gamma=\frac{1}{2} \frac{(\omega-1)(1-\tau)}{\tau \zeta+(1-\zeta)(\omega-1)(1-\tau)}
$$

This latter value is precisely the level $\gamma$ would take in the static model if a fraction $\tau$ of prices were preset.

The values of Home and Foreign equities are determined by the expected present discounted value of current and future profits of the firms. Would we not expect that the long-run effects of productivity growth on dividend growth and labor income growth wash out any temporary effects from price stickiness? Why would temporarily sticky prices matter so much?

The answer is that when goods prices adjust, terms of trade movements play an independent role in hedging consumption risk for households. When the home country, for example, has a negative productivity shock, its export price rises because the supply of its good has diminished. The increase in the relative price of its import tends to soften the blow from the negative productivity outcome. Indeed, as Cole and Obstfeld (1991) point out, when the elasticity of substitution between home and foreign goods is unity $(\omega=1)$, the terms of trade movements provide complete consumption insurance without the need for any asset trade. 24

The implication for portfolio choice is that the gains in households' utility from diversifying their equity portfolios are reduced by the terms-of-trade effect. The optimal portfolio under flexible prices exhibits bias toward foreign equities, but the gains (in expected utility) from diversifying the equity portfolio are small when $\omega$ is close to one. The terms of trade carry most of the load in diversifying risk when goods prices are flexible. Therefore, deviations from the optimal equity portfolio do not impose much utility cost when $\omega$ is close to one. But this insurance from terms of trade is not present when nominal prices are sticky. The terms of trade do not necessarily worsen with a positive productivity shock or improve with a negative productivity shock when nominal prices are sticky. In the short run, the asset portfolio (equities and foreign exchange hedge) must insure against risk. In the limit, as $\omega$ goes to one, only the short run matters, because, in the future, when goods prices are expected to adjust fully, the terms of trade will ensure the complete-markets

\footnotetext{
${ }^{24}$ Heathcote and Perri (2008) assume $\omega=1$, but assume that there is investment in capital and trade only in equities, and find that home bias can arise even with flexible goods prices. Baxter, Jermann, and King (1998) emphasize the importance of elasticity of substitution between traded and nontraded goods in a flexible price model for the equity portfolio.
} 
allocation. Then, in the limit, the optimal portfolio is determined by the diversification needs of the current period when goods prices are sticky.

In our model, a fraction $\tau$ of the firms have set the price in advance for a single period. Hold money supplies constant. The response of the cash flow of those firms to a relative productivity shock, $\hat{a}_{t}^{R}$, is given by $\Omega$, defined above.

In the period that a shock occurs, a fraction $1-\tau$ firms adjust their price freely. The impact of a relative productivity shock on their cash flow is given by $(\psi+1)(1-\tau)(\omega-1) /[1+\omega(1-\tau) \psi]$. The period after the shock, all firms adjust their prices. The expected discounted impact on cash flow from a relative productivity shock is given by $[(\psi+1)(\omega-1) /(1+\omega \psi)] \beta \vartheta_{R} /\left(1-\beta \vartheta_{R}\right)$. Adding the initialperiod effect to the long-run effect, we get the total effect of a one-unit change in $\hat{a}_{t}^{R}$ on the expected discounted cash-flow of firms that are adjusting their goods price to be $\Lambda$, defined above.

In these expressions, to be clear, the cash flow to sticky price firms refers to the one period during which the measure $\tau$ firms have set prices in advance. After the period in which the shocks occur, all firms are flexible-price firms. Nonetheless, the response of cash flow among sticky price firms can be much larger than the discounted sum of cash flow to flexible-price firms. For simplicity, if all firms were initially sticky price $(\tau=1)$, we see from these expressions that the impact of $\hat{a}_{t}^{R}$ on the sticky-price firms' initial cash flow is given by $(\psi+1) \zeta /(1-\zeta)$. But the impact on the present discounted value of cash flow after the period of the shock is given by $[(\psi+1)(\omega-1) /(1+\omega \psi)] \beta \vartheta_{R} /\left(1-\beta \vartheta_{R}\right)$. Although the latter cash flow is enlarged because it represents the cash flow over an infinite horizon, and so is multiplied by $\beta \vartheta_{R} /\left(1-\beta \vartheta_{R}\right)$, there are two other factors that work to make the effect on the cash flow after the initial period small relative to the initial-period effect. First, under flexible prices the terms of trade changes dampen the effects of productivity shocks on firm revenues. That channel does not exist in the initial period under sticky prices. So, $(\omega-1) /(1+\omega \psi)$ multiplies the cash flow in $\Lambda$, but not in $\Omega$. This works to reduce the effect of relative productivity shocks on $\Lambda{ }^{25}$ Second, in the initial period, firms do not "share" the benefit of the productivity increase with workers, so the initial effect when prices are sticky is multiplied by $\zeta /(1-\zeta)$.

Formally, we can evaluate the effect of increasing price stickiness on the optimal portfolio, $\gamma$, starting from a situation in which all goods prices are flexible $(\tau=0)$. We find

$$
\left.\frac{\partial \gamma}{\partial \tau}\right|_{\tau=0}=-\frac{1}{2} \frac{\zeta}{(1-\zeta)^{2}} \frac{1-\beta \vartheta_{R}}{\omega-1}
$$

The limit of this derivative as $\omega$ approaches unity from above is negative infinity. More generally, if the elasticity of substitution between Home and Foreign goods is not too different than one, a small amount of price stickiness can have a large effect on the portfolio. In the next section, we use values of the parameters of this model

\footnotetext{
${ }^{25}$ This could increase the effect of relative productivity shocks on $F L$ in the empirically implausible case that $\psi<1$ and $\omega>2 /(1-\psi)$.
} 
from calibrated general equilibrium models in the literature and find that the amount of home bias implied by the model is considerable.

We note that the portfolio allocations are unaffected by monetary policy. All monetary supply changes, whether they are independent monetary shocks or changes in reaction to productivity innovations, are hedged by the forward position. From the budget constraint, one can see that the optimal forward position will offset changes in the money supply. The equity position is determined to offset the change induced by shocks to technology, holding the money supplies constant. So neither the equity position nor the forward position is affected by monetary policy.

The comments about the forward position in the static model, at the end of Section II, apply here as well. The model implies an optimal forward position in which agents take a short position in foreign exchange.

\section{Calibrated Portfolios}

We can calibrate the amount of home bias implied by the model when an exchange rate hedge is present. Although the model is not realistic enough to capture some features of the macroeconomy, especially in that it assumes agents fully utilize the forward position to hedge exchange rate risk, it is still worthwhile to get a sense of the magnitude of home bias implied by the solution in equation (68). The share of the Home household's equity portfolio held in foreign shares, $\gamma$, depends on the price stickiness parameter, $\tau$; labor's share, $\zeta$; the elasticity of substitution between Home and Foreign aggregates, $\omega$; the discount factor, $\beta$; the persistence of relative productivity shocks, $\vartheta_{R}$; and, the elasticity of labor supply, $\psi$.

Following David K. Backus, Patrick J. Kehoe, and Finn E. Kydland (1992), we set $\zeta=2 / 3$. We follow Obstfeld and Rogoff (2003), and Paul R. Bergin (2006), and set $\psi=1$.

In most calibrations of new-Keynesian models with nominal price stickiness, the expected life of a nominal price (under Calvo price setting) is calibrated to be four quarters. 26 Our model of price stickiness does not translate easily into the Calvo framework, however, where the life of a price follows a Poisson process. In our model, a measure $\tau$ of firms set prices for one period, and a measure $1-\tau$ adjust prices instantaneously. So the expected life of a price is $\tau$ periods. We calibrate the degree of price stickiness in the following way. We consider different values for $\tau$, ranging from 0.05 to 1 . We can then set the length of a period so that the fraction $\tau$ of a period equals four quarters, or one period equals $4 / \tau$ quarters. In Table 1 , we present the equity shares we have calculated for the various values of $\tau$.

The estimates of Backus, Kehoe, and Kydland (1992) give us on quarterly data that the autocorrelation of relative productivity shocks is 0.855 , so we set $\vartheta_{R}$ $=(0.855)^{4 / \tau}$. Likewise, the quarterly discount factor in Backus et al. is 0.99, so we take $\beta=(0.99)^{4 / \tau}$.

Backus, Kehoe, and Kydland (1994), and V. V. Chari, Kehoe, and Ellen R. McGrattan (2002) set $\omega=1.5$. In some real business cycles, however, the elasticity

\footnotetext{
${ }^{26}$ Taylor (1999) is usually cited as a source for this calibration. See, for example, Kevin X. D. Huang and Zheng Liu (2005).
} 
Table 1 -Optimal Portfolio Shares of Foreign Equities

\begin{tabular}{lcccccc}
\hline \hline & $\omega=1$ & $\omega=1.1$ & $\omega=1.5$ & $\omega=2$ & $\omega=3$ & $\omega=6$ \\
\hline$\tau=1.00$ & 0.00 & 0.04 & 0.14 & 0.22 & 0.31 & 0.41 \\
$\tau=0.95$ & 0.00 & 0.04 & 0.17 & 0.27 & 0.39 & 0.57 \\
$\tau=0.90$ & 0.00 & 0.05 & 0.19 & 0.31 & 0.46 & 0.69 \\
$\tau=0.85$ & 0.00 & 0.05 & 0.21 & 0.35 & 0.52 & 0.79 \\
$\tau=0.80$ & 0.00 & 0.06 & 0.24 & 0.39 & 0.58 & 0.87 \\
$\tau=0.75$ & 0.00 & 0.06 & 0.26 & 0.43 & 0.64 & 0.94 \\
$\tau=0.70$ & 0.00 & 0.07 & 0.29 & 0.47 & 0.69 & 0.99 \\
$\tau=0.65$ & 0.00 & 0.08 & 0.31 & 0.51 & 0.74 & 1.05 \\
$\tau=0.60$ & 0.00 & 0.09 & 0.34 & 0.55 & 0.79 & 1.09 \\
$\tau=0.55$ & 0.00 & 0.10 & 0.38 & 0.59 & 0.84 & 1.13 \\
$\tau=0.50$ & 0.00 & 0.11 & 0.41 & 0.64 & 0.89 & 1.17 \\
$\tau=0.45$ & 0.00 & 0.12 & 0.45 & 0.68 & 0.94 & 1.20 \\
$\tau=0.40$ & 0.00 & 0.13 & 0.49 & 0.74 & 0.98 & 1.24 \\
$\tau=0.35$ & 0.00 & 0.15 & 0.54 & 0.79 & 1.03 & 1.27 \\
$\tau=0.30$ & 0.00 & 0.18 & 0.60 & 0.86 & 1.09 & 1.30 \\
$\tau=0.25$ & 0.00 & 0.21 & 0.67 & 0.93 & 1.15 & 1.33 \\
$\tau=0.20$ & 0.00 & 0.26 & 0.76 & 1.01 & 1.21 & 1.37 \\
$\tau=0.15$ & 0.00 & 0.33 & 0.88 & 1.11 & 1.28 & 1.40 \\
$\tau=0.10$ & 0.00 & 0.47 & 1.04 & 1.23 & 1.35 & 1.44 \\
$\tau=0.05$ & 0.00 & 0.73 & 1.24 & 1.36 & 1.43 & 1.47 \\
\hline
\end{tabular}

Notes: The table presents optimal portfolio share calculated from equation (68) for parameter values described in text. The portfolio value is calculated for various values of the elasticity of substitution, $\omega$, and for various values of the fraction of firms that set prices in advance, $\tau$. Portfolio shares of less than one-half $(\gamma<1 / 2)$ indicate home bias in equity portfolios.

of substitution is even lower (see, for example, Bergin 2006; Heathcote and Perri 2002). In Table 1, we consider a range of values for $\omega$, from one to six, to explore the role of this parameter in determining the optimal equity portfolio.

Table 1 presents a grid of possible values of the portfolio, which depend on $\omega$ and the value of $\tau$. The model is symmetric between Home and Foreign countries, so an unbiased portfolio would be $\gamma=0.5$. When the elasticity of substitution, $\omega$, is low, the portfolio exhibits a high degree of home bias in equity holdings when prices are sticky. For example, under the parameterization in which $\omega=1.5$, the portfolio exhibits home bias as long as at least 40 percent of firms adjust prices with a lag. This finding should be compared to the prediction of the flexible-price model, which has the strong anti-home bias of Baxter and Jermann (1997) with $\gamma^{\text {FLEX }}=1.5$. Just a small amount of price stickiness substantially changes the optimal portfolio, moving it in the direction of holding a greater share of home equities. That effect is even more pronounced for lower values of $\omega$ that have been used in the literature. For example, when $\omega=1.1$, the share of Foreign equities held in the Home equity portfolio is only 10 percent, when as few as 55 percent of firms have sticky prices. Table 1 illustrates the importance of the magnitude of the elasticity of substitution between Home and Foreign goods for delivering the home bias result under sticky prices. If $\omega$ is as large as six, the optimal portfolio for Home households requires a bias in favor of Foreign equities, except in the case in which all firms have sticky prices. 
It is worthwhile to repeat the significance of these findings. Rather than take the view that this model explains home bias in equity holdings, we prefer to interpret this table as illustrating that the complete markets equilibrium could be replicated with very little equity diversification when nominal prices are sticky. But a requirement for that equilibrium is that households take an appropriate foreign exchange hedge.

\section{Conclusion}

Our model provides a general equilibrium analysis of the factors that determine equilibrium portfolio choice in a dynamic setting. Sticky-price portfolio balance models have been a staple of open-economy macroeconomics for decades, but until now there was no fully integrated dynamic stochastic equilibrium model. Our model is, we believe, a starting point. We are able to solve the model in closed form, and, therefore, we can provide some novel insights into the interplay between financial markets and the macroeconomy.

We have stressed a few of these features. First, we have demonstrated that even a small amount of nominal rigidity_-price setting with a relatively short durationcan dramatically alter equilibrium equity portfolios. Second, our model shows the role of nominally denominated assets in hedging real risks when nominal goods prices are sticky.

Future research may help refine the role of nominal bonds, or a forward position in foreign exchange, in insuring consumption risk when nominal prices are sticky. Here, we mention three special features of the dynamic model, and hypothesize how our results are affected by them. In each case, we note that the static model of Section I has generalized these assumptions, and that model gives us a guide toward how a generalized dynamic model will look.

First, in our dynamic model, we have assumed goods prices are set in the currency of the household/consumer. That is, firms in each country set two prices, one in their own currency for local sales and one in the currency of the importer for export sales. But, in fact, the currency of price setting for goods will not matter at all for the optimal equity portfolio. If firms set prices in their own currency (producercurrency pricing) or indexed prices to the exchange rate, that would have the effect of altering the exchange-rate risk facing households. However, exchange-rate risk is hedged using the forward position in foreign exchange. The pricing behavior of firms affects the forward position of households but not the equity position-as long as households can freely hedge their foreign exchange risk so that the complete markets allocations are attainable.

Second, our dynamic model assumes that nominal wages are determined in competitive labor markets. Suppose that nominal wages also were sticky. It is easy to see how households may want to diversify their equity portfolio, even with a foreign exchange hedge available, if wages are very inflexible. Suppose, for example, that all wages are set one period in advance, and prices are fully flexible. Obstfeld (2007) considers this case in the context of our static model. Suppose there is a positive productivity shock in the Home country. This will tend to lower the relative price of the Home good immediately, because it is priced flexibly. But the real wage will 
increase, because nominal wages are fixed. Profits and real wages move in the same direction, even holding the exchange rate constant. So, real risks are not fully hedged if households hold only Home, and not Foreign, equities. More generally, the amount of diversification of the equity portfolio required to support the complete markets allocation will increase when wage stickiness is introduced. With a high degree of price stickiness, the equity portfolio that delivers the complete-markets allocation may still exhibit a high degree of home bias. Recall that in the static model, when all nominal prices are sticky, the optimal equity portfolio exhibits complete home bias, irrespective of the degree of wage stickiness.

Third, our dynamic model assumes identical preferences for Home and Foreign households. We have seen, in the static model with complete price stickiness, that allowing for home bias in preferences does not alter the optimal equity portfolio. But more generally in the dynamic framework, home bias in preferences will alter the equilibrium portfolio of equities needed to deliver the complete-markets allocation. We know that when prices are flexible, home bias in preferences can influence the equity portfolio. This, in turn, must affect the portfolio under temporarily sticky prices.

As has been noted abundantly in the recent literature (see Obstfeld 2007, for an example), the condition that arises under complete risk sharing relating relative Home to Foreign consumption on the one hand, and the real exchange rate on the other (see equation (10)), appears to be strongly violated in the data. Our study suggests that at least part of the blame for incomplete risk sharing is that the exchange rate positions taken by countries do not optimally share risk. That is, we suggest when there are sticky prices that the forward position in foreign exchange may be the culprit in incomplete risk sharing.

\section{REFERENCES}

- Backus, David K., Patrick J. Kehoe, and Finn E. Kydland. 1992. "International Real Business Cycles." Journal of Political Economy, 100(4): 745-75.

Backus, David K., Patrick J. Kehoe, and Finn E. Kydland. 1994. "Dynamics of the Trade Balance and the Terms of Trade: The J-Curve?" American Economic Review, 84(1): 84-103.

Baxter, Marianne, and Urban J. Jermann. 1997. "The International Diversification Puzzle Is Worse Than You Think." American Economic Review, 87(1): 170-80.

Baxter, Marianne, Urban J. Jermann, and Robert G. King. 1998. "Nontraded Goods, Nontraded Factors, and International Non-Diversification." Journal of International Economics, 44(2): 211-29.

Bergin, Paul R. 2006. "How Well Can the New Open Economy Macroeconomics Explain the Exchange Rate and the Current Account?" Journal of International Money and Finance, 25(5): 675-701.

Blanchard, Olivier Jean, and Nobuhiro Kiyotaki. 1987. "Monopolistic Competition and the Effects of Aggregate Demand." American Economic Review, 77(4): 647-66.

Bottazzi, Laura, Paolo Pesenti, and Eric van Wincoop. 1996. "Wages, Profits and the International Portfolio Puzzle." European Economic Review, 40(2): 219-54.

-Chari, V. V., Patrick J. Kehoe, and Ellen R. McGrattan. 2002. "Can Sticky Price Models Generate Volatile and Persistent Real Exchange Rates?" Review of Economic Studies, 69(3): 533-63.

- Cole, Harold L., and Maurice Obstfeld. 1991. "Commodity Trade and International Risksharing: How Much Do Financial Markets Matter?" Journal of Monetary Economics, 28(1): 3-24.

Corsetti, Giancarlo, and Paolo Pesenti. 2005. "International Dimensions of Optimal Monetary Policy.” Journal of Monetary Economics, 52(2): 281-305.

Coeurdacier, Nicolas, Robert Kollmann, and Philippe Martin. Forthcoming. "International Portfolios with Supply, Demand and Redistributive Shocks." In NBER International Seminar on Macroeconomics 2007, ed. Richard Clarida and Francesco Giavazzi. Chicago, IL: University of Chicago Press. 
Devereux, Michael B., and Alan Sutherland. 2006. "Solving for Country Portfolios in Open Economy Macro Models." Centre for Economic Policy Research Discussion Paper 5966.

Devereux, Michael B., and Alan Sutherland. 2007. "Country Portfolio Dynamics." Centre for Economic Policy Research Discussion Paper 6208.

Devereux, Michael B., and Alan Sutherland. 2008a. "Financial Globalization and Monetary Policy." Journal of Monetary Economics, 55(8): 1363-75.

Devereux, Michael B., and Alan Sutherland. 2008b. "Valuation Effects and the Dynamics of Net External Assets." Paper presented at the International Monetary Fund Conference on International Macro-Finance, Washington, DC.

Eldor, Rafael, David Pines, and Abba Schwartz. 1988. "Home Asset Preference and Productivity Shocks." Journal of International Economics, 25(1-2): 165-76.

Engel, Charles. 2006. "Equivalence Results for Optimal Pass-Through, Optimal Indexing to Exchange Rates, and Optimal Choice of Currency for Export Pricing." Journal of the European Economics Association, 4(6): 1249-60.

Evans, Martin D. D., and Viktoria Hnatkovska. 2008. "A Method for Solving General Equilibrium Models with Incomplete Markets and Many Financial Assets." http://www.econ.ubc.ca/ vhnatkovska/Research/solumethod_Evans_Hnatkovska.pdf.

French, Kenneth R., and James M. Poterba. 1991. "Investor Diversification and International Equity Markets." American Economic Review, 81(2): 222-26.

Heathcote, Jonathan, and Fabrizio Perri. 2002. "Financial Autarky and International Business Cycles." Journal of Monetary Economics, 49(3): 601-27.

Heathcote, Jonathan, and Fabrizio Perri. 2008. "The International Diversification Puzzle is not as Bad as You Think." http://www9.georgetown.edu/faculty/jhh9/homebias.pdf.

Huang, Kevin X. D., and Zheng Liu. 2005. "Inflation Targeting: What Inflation Rate to Target?" Journal of Monetary Economics, 52(8): 1435-62.

Jermann, Urban J. 2002. "International Portfolio Diversification and Endogenous Labor Supply Choice." European Economic Review, 46(3): 507-22.

Julliard, Christian. 2002. "The International Diversification Puzzle is Not Worse than You Think." Unpublished.

Julliard, Christian. 2004. "Human Capital and International Portfolio Choice." http://personal.lse. ac.uk/julliard/papers/IPD.pdf.

Lewis, Karen K. 1999. "Trying to Explain Home Bias in Equities and Consumption.” Journal of Economic Literature, 37(2): 571-608.

Lewis, Karen K. 2000. "Why Do Stocks and Consumption Imply Such Different Gains from International Risk Sharing?" Journal of International Economics, 52(1): 1-35.

Lucas, Robert E., Jr. 1982. "Interest Rates and Currency Prices in a Two-Country World.” Journal of Monetary Economics, 10(3): 335-59.

Lustig, Hanno, and Stijn van Nieuwerburgh. 2008. "The Returns on Human Capital: Good News on Wall Street is Bad News on Main Street." Review of Financial Studies, 21(5): 2097-2137.

Matsumoto, Akito. 2004. "Essays in International Finance." PhD diss. University of Wisconsin.

Matsumoto, Akito. 2007. "The Role of Nonseparable Utility and Nontradeables in International Business Cycle and Portfolio Choice.” International Monetary Fund Working Paper 07/163.

Obstfeld, Maurice. 2007. "International Risk Sharing and the Costs of Trade." Ohlin Lectures, Stockholm School of Economics. http://elsa.berkeley.edu/ obstfeld/Ohlin_show.pdf.

Obstfeld, Maurice, and Kenneth Rogoff. 1996. Foundations of International Macroeconomics. Cambridge, MA: MIT Press.

Obstfeld, Maurice, and Kenneth S. Rogoff. 2003. "Risk and Exchange Rates." In Contemporary Economic Policy: Essays in Honor of Assaf Razin, ed. Elhanan Helpman and Efraim Sadka, 74-120. Cambridge, UK: Cambridge University Press.

Palacios-Huerta, Ignacio. 2001. "The Human Capital of Stockholders and the International Diversification Puzzle." Journal of International Economics, 54(2): 309-31.

Pesenti, Paolo, and Eric van Wincoop. 2002. "Can Nontradables Generate Substantial Home Bias?" Journal of Money, Credit, and Banking, 34(1): 25-50.

Stockman, Alan C., and Harris Dellas. 1989. "International Portfolio Nondiversification and Exchange Rate Variability." Journal of International Economics, 26(3-4): 271-89.

Taylor, John B. 1999. "Staggered Price and Wage Setting in Macroeconomics." In Handbook of Macroeconomics, Vol. 1B, ed. John B. Taylor and Michael Woodford, 1009-1050. Amsterdam: Elsevier.

Tesar, Linda L. 1993. "International Risk Sharing and Non-Traded Goods.” Journal of International Economics, 35(1-2): 69-89. 
Tesar, Linda L., and Ingrid M. Werner. 1995. "Home Bias and High Turnover." Journal of International Money and Finance, 14(4): 467-92.

Tille, Cedric, and Eric van Wincoop. 2008a. "International Capital Flows.” http://www.people. virginia.edu/ ev4n/papers/capflows_Apr_18.pdf.

Tille, Cedric, and Eric van Wincoop. 2008b. "A New Perspective on 'The New Rule' of the Current Account." http://www.people.virginia.edu/ ev4n/papers/kraay_June_27.pdf.

Warnock, Francis E. 2002. "Home Bias and High Turnover Reconsidered." Journal of International Money and Finance, 21(6): 795-805. 